\title{
Review Article \\ Cross-Talk between Oxidative Stress and Inflammation in Preeclampsia
}

\author{
Marilene Brandão Tenório, ${ }^{1,2}$ Raphaela Costa Ferreira, ${ }^{3}$ Fabiana Andréa Moura, ${ }^{1}$ \\ Nassib Bezerra Bueno, ${ }^{1}$ Alane Cabral Menezes de Oliveira ${ }^{(D)}{ }^{1}$ \\ and Marília Oliveira Fonseca Goulart $\mathbb{i D}^{2,3}$
}

${ }^{1}$ Faculdade de Nutrição, Universidade Federal de Alagoas, Campus A.C. Simões, BR 104 Norte, Km 96, 7, Tabuleiro dos Martins, CEP 57.072-970 Maceió, Alagoas, Brazil

${ }^{2}$ Instituto de Química e Biotecnologia (IQB/UFAL), Rede Nordeste de Biotecnologia (RENORBIO), Universidade Federal de Alagoas, Campus A.C. Simões, BR 104 Norte, Km 96, 7, Tabuleiro dos Martins, CEP 57.072-970 Maceió, Alagoas, Brazil

${ }^{3}$ Programa de Pós-graduação em Ciências da Saúde, ICBS, Universidade Federal de Alagoas, Campus A.C. Simões, BR 104 Norte, Km 96, 7, Tabuleiro dos Martins, CEP 57.072-970 Maceió, Alagoas, Brazil

Correspondence should be addressed to Alane Cabral Menezes de Oliveira; alanecabral@gmail.com and Marília Oliveira Fonseca Goulart; mariliaofg@gmail.com

Received 30 May 2019; Accepted 9 September 2019; Published 4 November 2019

Academic Editor: Daniela Giustarini

Copyright (C) 2019 Marilene Brandão Tenório et al. This is an open access article distributed under the Creative Commons Attribution License, which permits unrestricted use, distribution, and reproduction in any medium, provided the original work is properly cited.

\begin{abstract}
The occurrence of hypertensive syndromes during pregnancy leads to high rates of maternal-fetal morbidity and mortality. Amongst them, preeclampsia (PE) is one of the most common. This review aims to describe the relationship between oxidative stress and inflammation in PE, aiming to reinforce its importance in the context of the disease and to discuss perspectives on clinical and nutritional treatment, in this line of research. Despite the still incomplete understanding of the pathophysiology of $\mathrm{PE}$, it is well accepted that there are placental changes in pregnancy, associated with an imbalance between the production of reactive oxygen species and the antioxidant defence system, characterizing the placental oxidative stress that leads to an increase in the production of proinflammatory cytokines. Hence, a generalized inflammatory process occurs, besides the presence of progressive vascular endothelial damage, leading to the dysfunction of the placenta. There is no consensus in the literature on the best strategies for prevention and treatment of the disease, especially for the control of oxidative stress and inflammation. In view of the above, it is evident the important connection between oxidative stress and inflammatory process in the pathogenesis of PE, being that this disease is capable of causing serious implications on both maternal and fetal health. Reports on the use of anti-inflammatory and antioxidant compounds are analysed and still considered controversial. As such, the field is open for new basic and clinical research, aiming the development of innovative therapeutic approaches to prevent and to treat PE.
\end{abstract}

\section{Introduction}

Preeclampsia (PE) is one of the most common gestational complications, being clinically characterized by a systolic blood pressure of $140 \mathrm{mmHg}$ or higher, a diastolic blood pressure of $90 \mathrm{mmHg}$ or higher, or both systolic and diastolic blood pressure above $\geq 140 / 90 \mathrm{mmHg}$, measured twice with a four-hour interval, with proteinuria in $24 \mathrm{~h}$ urine $\geq 300 \mathrm{mg}$ or protein/creatinine ratio $\geq 0.3$. In the absence of quantitative methods, a $1+$ test tape in the urine proteins may be used [1-3]. However, in the absence of proteinuria, PE is diagnosed associated with elevated blood pressure levels, using the following criteria: thrombocytopenia (number of thrombocytosis less than $100,000 / \mu \mathrm{L}$ ), renal insufficiency (serum creatinine above $97 \mu \mathrm{mol} / \mathrm{L}$ ), reduced liver function (enzymatic activity AST and ALT two times higher than the 
reference range limit, being for $\mathrm{AST} \geq 60 \mathrm{UI} / \mathrm{L}$ and for $\mathrm{ALT} \geq 64 \mathrm{UI} / \mathrm{L}$ ), and pulmonary edema, cerebral, or visual disturbances [4].

Although the pathophysiological mechanisms of PE remain obscure, it is known that placental changes occur early in pregnancy, associated with an imbalance between the generation of reactive oxygen species (ROS) and the antioxidant defence system, characterizing oxidative stress. There is also a generalized inflammatory process, as well as the presence of progressive vascular endothelial damage, which culminates in placental dysfunction [5]. Despite this, it is not well established if the oxidative stress is the result of generalized oxidative cellular damage, which can affect proteins, lipid membranes, and deoxyribonucleic acid (DNA), caused by the disease already established, or if it precedes the clinical establishment of $\mathrm{PE}$, being involved in its pathogenesis $[6,7]$.

Considering the above, this review aims to describe the relationship between oxidative stress and inflammation in $\mathrm{PE}$, contributing to reinforce their importance in the context of the disease and to discuss perspectives on clinical and nutritional treatment in this research line.

\section{Pathophysiology of PE}

2.1. Trophoblastic and Placental Invasion: Normal Gestation vs. PE Gestation. The placenta, a highly complex membranous vascular organ, is developed during gestation and is responsible for the metabolic interaction between the mother and fetus, such as transport of oxygen and nutrients, fetal metabolite elimination and the production of hormones, as human chorionic gonadotropin hormone, estrogen, progesterone, and human placental lactogen $[8,9]$. It has a diameter of 15 to $17 \mathrm{~cm}$ and an approximate weight of $500 \mathrm{~g}$ in a term gestation. Its growth is proportional to the gestational period; i.e., the placenta grows as the pregnancy progresses [10]. Some pathological conditions can trigger placental insufficiency, such as hypertension, diabetic vasculopathy, and anatomical disorders. Thus, changes in maternal homeostasis may modify placental structure and function and thereby affect fetal growth [10].

In the development of healthy gestation, the trophoblastic cells are assigned to invade the maternal endometrium and cause remodeling of the spiral arteries, aiming to increase their calibers and consequent supply of oxygenated blood and nutrients to the placenta $[11,12]$. In women who develop PE, an abnormal trophoblastic invasion occurs early in pregnancy, which implies poor oxygenation of the intervillous space and persistence of the primary characteristics of the uterine spiral arteries, maintaining their high resistance. Thus, because there is no remodeling of these arteries, there is less oxygenated blood supply and nutrients, causing the placenta to be reduced in size. This process of hypoxia/reperfusion is always marked by an exacerbated production of ROS, when oxygen molecules are reintroduced into the tissue, after occurrence of hypoxia, leading to oxidative stress $[13,14]$.

Among the mechanisms proposed to explain the relationship between hypoxia and the ROS presence, problems during the aerobic cellular respiration are initially included. Thus, as oxygen $\left(\mathrm{O}_{2}\right)$ concentration decreases within the cell, there is also a decrease in oxidative phosphorylation and lower formation of adenosine triphosphate (ATP), which result in dysfunction on several intracellular systems [15]. Besides, an increase in the production of ROS occurs through mitochondria, which can lead to lesion and/or cell death [16, 17].

In addition, a possible rise in cytosolic calcium, caused probably by the ischemia/reperfusion process, leads to the activation of the protease calpain, responsible for promoting the breakdown of a peptide bridge of the enzyme xanthine dehydrogenase, leading to the formation of the enzyme xanthine oxidase, which in turn, requires oxygen to perform the transformation of hypoxanthine into xanthine. In the ischemia stage, therefore, accumulation of these two substances occurs. With reperfusion, the hypoxanthine is oxidized to xanthine-which is increased in women with PE $[16,18,19]$ - and subsequently in uric acid, generating as byproducts of this reaction the superoxide radical anion $\left(\mathrm{O}_{2}{ }^{--}\right)$- which may be generated by electron capture in the mitochondrial transport system or via cyclooxygenase in the metabolism of arachidonic acid [20, 21] - hydrogen peroxide, and, in the presence of divalent ions, such as iron and copper, hydroxyl radicals $\left({ }^{\bullet} \mathrm{OH}\right)$ [16]. In this way, the activation of nonspecific proteases and phospholipases occurs, in response to the rise in intracellular calcium, during reperfusion, and results in the synthesis of proinflammatory mediators, such as platelet activating factor, leukotrienes, thromboxanes, and prostaglandins [22].

Thus, the presence of both trophoblast and placenta, and not necessarily the fetus, is essential for the PE development, since the disease also affects molar pregnancies (where genetically abnormal placental tissue proliferates in the absence of the fetus, giving rise to tumors and gestational trophoblastic disorders). In addition, the greater the placental mass, as in multiple pregnancies, the greater the risk of developing this disease, because the placenta is covered by a syncytiotrophoblast, a type of multinucleated cell with high invasive potential that will aid in the embryo implantation in the maternal endometrium. When there is some type of damage in these cells, trophoblastic fragments are released into the maternal circulation, with signaling to the endothelial cells, which phagocyte them in normal situations. However, in PE, there is also a compromise in the activity of endothelial cells, which makes it difficult to remove these fragments, and although it is not clear which placental factor is responsible for triggering PE, it is known that the increase of trophoblastic fragments in the circulation is related to the onset of the disease [23].

Regarding the changes in placental architecture, considering the morphological and functional characteristics, placentas from pregnant women with PE present diameter, thickness, weight, volume, cord size, and number of cotyledons smaller than usual. In addition, areas with bruise, infarction, and clot presence, with a marginal and paracentral cord insertion, in comparison with normal placentas, which present insertion of the central cord, are present [24-26]. 


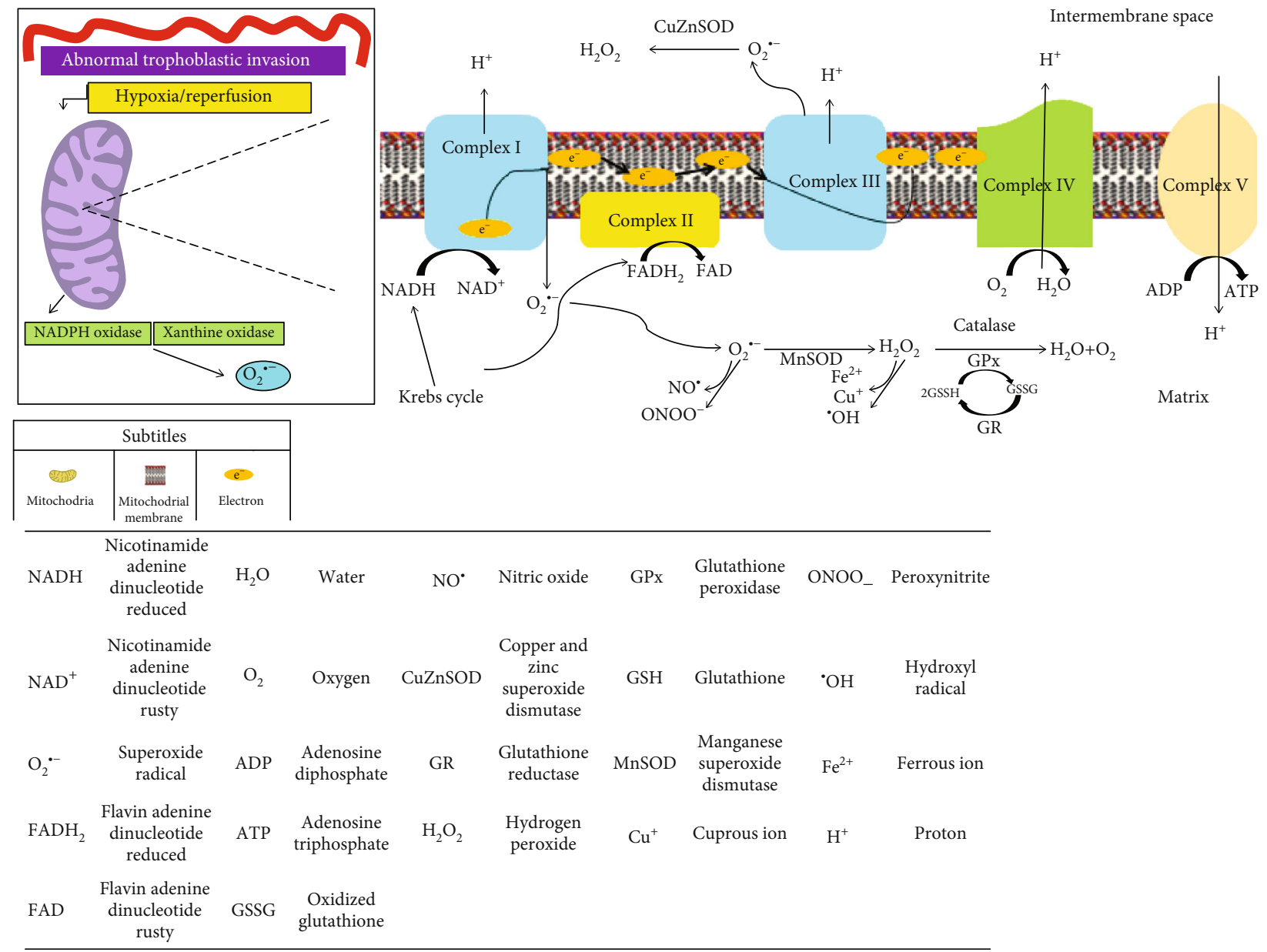

FIGURE 1: Mitochondrial production of some reactive oxygen species. The reduced perfusion due to impaired trophoblastic invasion triggers a condition of oxidative stress in the placenta by some mechanisms: (a) perfusion that can lead to repeated hypoxia/reoxygenation, a potent stimulus for the activation of the xanthine oxidase and nicotinamide adenine dinucleotide phosphate oxidase (NADPH oxidase), enzymes that are important precursors in the formation of $\mathrm{O}_{2}{ }^{--}$[28-30]; (b) the hypoxia/reperfusion also stimulates the electron transport chain, specifically complexes I and III [31], which increases the $\mathrm{O}_{2}^{-{ }^{--}}$production [28]. In the mitochondrial matrix, manganese superoxide dismutase (MnSOD) or copper and zinc superoxide dismutase (CuZnSOD) in the intermembrane space catalyzes the conversion of $\mathrm{O}_{2}{ }^{--}$to hydrogen peroxide $\left(\mathrm{H}_{2} \mathrm{O}_{2}\right) \cdot \mathrm{H}_{2} \mathrm{O}_{2}$ can then be completely reduced to water by antioxidant enzymes, such as glutathione peroxidase (GPx) or catalase (CAT) [32, 33]. Adapted from Yiyenoğlu et al. [28], Redman [29], Poston et al. [30], Chamy et al. [32], and Raijmakers et al. [33].

2.2. PE vs. Oxidative Stress. Normal pregnancy is characterized as a prooxidant period, where ROS production occurs, characterizing oxidative stress, with reduced plasma levels of free antioxidants and increased purine catabolism. In many pregnancy-related disorders, including PE, this prooxidant characteristic is even more exacerbated [27].

Thus, scientific evidence suggests that reduced perfusion due to impaired trophoblastic invasion and aberrant placentation triggers a condition of oxidative stress in the placenta by the following mechanisms that increases $\mathrm{O}_{2}{ }^{--}$formation: (a) perfusion that can lead to repeated hypoxia/reoxygenation, a potent stimulus for the activation of the xanthine oxidase and the nicotinamide adenine dinucleotide phosphate oxidase (NADPH oxidase) [28-30]; (b) stimulation of the electron transport chain by the hypoxia/reperfusion and electron transport chain by the hypoxia/reperfusion, specifically complexes I and III [31]. Upon addition, in the mitochondrial matrix, of manganese superoxide dismutase (MnSOD) or copper and zinc superoxide dismutase (CuZnSOD) in the intermembrane space, the conversion of $\mathrm{O}_{2}{ }^{-0}$ to hydrogen peroxide $\left(\mathrm{H}_{2} \mathrm{O}_{2}\right)$ is catalyzed, followed by its reduction to water by glutathione peroxidase $(\mathrm{GPx})$ or catalase (CAT) $[32,33]$.

Figure 1 illustrates this process in the mitochondria.

The increase of oxidative stress in PE may also occur due to the increase in the circulating levels of tumor necrosis factor alpha (TNF- $\alpha$ ), which, indirectly, may be able to regulate, in a positive way, lectin-like oxidized low-density lipoprotein (LDL) receptor-1 (LOX-1). This regulation results in increased uptake of oxidized LDL, leading to increased $\mathrm{O}_{2}{ }^{--}$production, via activation of NADPH oxidase. Several compounds present in the plasma of women with PE can also activate LOX-1, such as phospholipids, platelets, cytokines, and apoptotic cell fragments, resulting in increased 


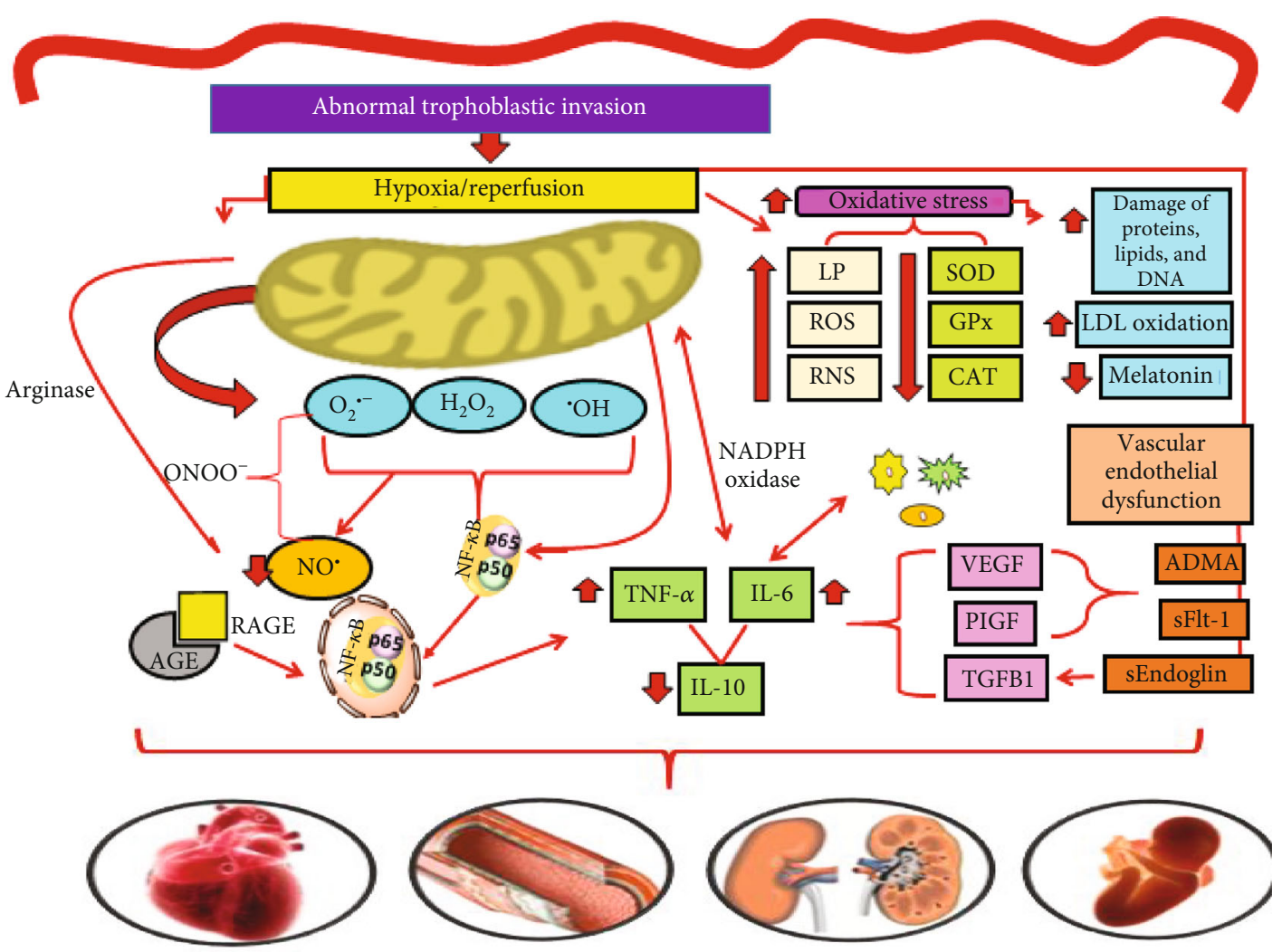

\begin{tabular}{|c|c|c|}
\hline \multicolumn{3}{|c|}{ Subtitles } \\
\hline $\begin{array}{c}\text { Cells of the } \\
\text { immune system }\end{array}$ & Mitochondria & Cell nucleus \\
& & \\
\hline
\end{tabular}

FIGURE 2: Mechanisms suggested in the pathophysiology of preeclampsia. The process of abnormal trophoblastic invasion, which culminates in repeated episodes of hypoxia/reperfusion, leads to the oxidative stress in PE. In turn, the process of hypoxia/reperfusion culminates with greater production of reactive oxygen species (ROS), reactive nitrogen species (RNS), and lipid peroxides, while the antioxidant defence is reduced, including SOD, GPx, and CAT, leading to an increased systemic oxidative stress condition, besides other factors resulting from oxidative stress, including damaged DNA, low-density lipoprotein (LDL) oxidation, and reduction in melatonin production [37]. Thus, there is a concomitant increase of the inflammatory response, through the cytokine production, such as tumor necrosis factor alpha (TNF- $\alpha$ ) and interleukin- (IL-) 6, which led to a reduction in the anti-inflammatory cytokine production, such as IL-10, and, consequently, cell damage $[14,36]$. In the inflammatory response, there is the involvement of genes related to oxidative stress, especially the nuclear factor kappa B (NF- $\kappa \mathrm{B})$, located in the cellular cytoplasm. ROS are able to oxidize the I $\kappa \mathrm{B}$ kinase (IKK) complex, leading to the release of NF- $\kappa \mathrm{B}$, which is formed by p50 and p65 subunits. Because it is a nuclear factor, the NF- $\kappa \mathrm{B}$ molecule enters the cell nucleus and promotes the transcription of several proinflammatory cytokines such as IL- 6 and TNF- $\alpha$. This process occurs naturally during gestation, but in the PE, its action is exacerbated [39, 96]. Advanced glycation end products (AGEs), resulting from the glycation of proteins or other biomolecules, interact with their receptors (RAGEs) located in a wide variety of tissues. Such interaction is responsible for triggering the activation of several signaling pathways, culminating with the activation of NF- $\kappa \mathrm{B}$, leading to an inflammatory process $[52,53]$. Beyond the inflammatory process, $\mathrm{PE}$ also results in endothelial dysfunction due to reduced bioavailability of nitric oxide $\left(\mathrm{NO}^{\bullet}\right)$ and increased production of placental antiangiogenic factors, such as dimethylarginine (ADMA), sEndoglin (soluble endoglin), and Fms-like receptor tyrosine kinase (sFlt-1). The association of these changes leads to health consequences, such as cardiovascular-, endothelial-, renal-, and fetal-related complications [38]. Legend: ADMA: dimethylarginine; AGE: advanced glycation end products; CAT: catalase; GPx: glutathione peroxidase; IL: interleukin; LP: lipid peroxides; NADPH oxidase: nicotinamide adenine dinucleotide phosphate oxidase; NF- $\kappa \mathrm{B}$ : nuclear factor kappa B; $\mathrm{ONOO}^{-}$: peroxynitrite; PIGF: placental growth factor; RAGE: advanced glycation end product receptors; RNS: reactive nitrogen species; ROS: reactive oxygen species; sFlt-1: soluble Fms-like receptor tyrosine kinase; SOD: superoxide dismutase; TGFB1: transforming growth factor beta; TNF- $\alpha$ : tumor necrosis factor alpha; VEGF: vascular endothelial growth. Adapted from Sanchéz-Araguren et al. [14], Harmon et al. [36], Chiarello et al. [37], Cheng et al. [38], Striz et al. [39], Rayman et al. [96], Sargent et al. [52], and Guedes-Martins et al. [53]. 


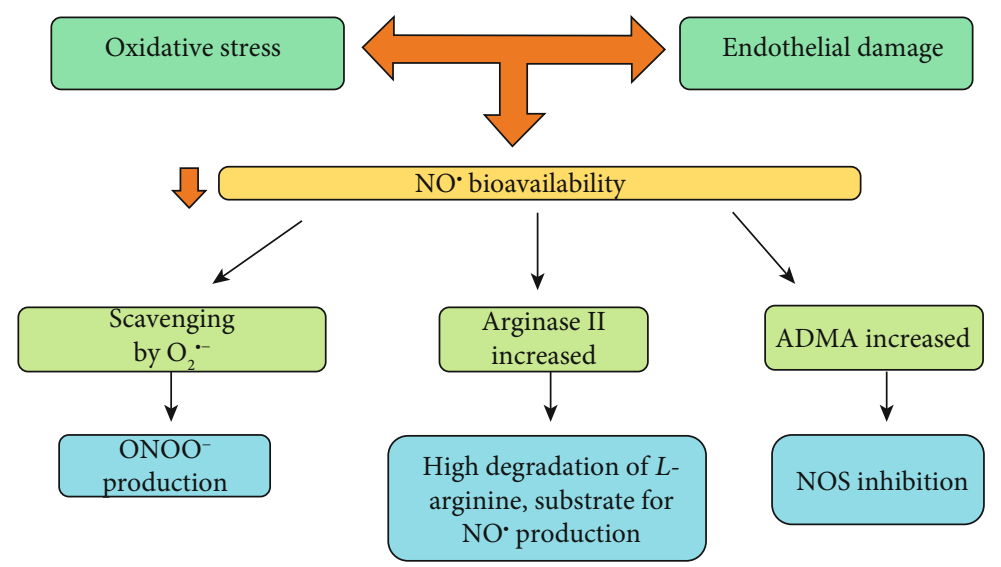

FIGURE 3: Routes through which the bioavailability of nitric oxide decreases in preeclampsia. Some pathways can contribute to the lower bioavailability of $\mathrm{NO}^{\bullet}$ in the PE. The first one involves ROS, where it is suggested that $\mathrm{O}_{2}{ }^{\bullet-}$ captures $\mathrm{NO}^{\bullet}$ for the formation of peroxynitrite $\left(\mathrm{ONOO}^{-}\right)$, which has a high redox potential [13]. In addition, $\mathrm{ONOO}^{-}$reacts with lipids, leading to lipid peroxidation (LP) and generation of malondialdehyde (MDA) and its conjugates [97]. The second path involves the increase in the production of the enzyme arginase, responsible for catalyzing the conversion of $L$-arginine to $L$-ornithine and urea [98]. Therefore, the bioavailability of arginine for $\mathrm{NO}^{\bullet}$ formation is compromised $[99,100]$. The last one involves the presence of ADMA, an endogenous inhibitor of the enzyme nitric oxide synthase (eNOS), which is increased in PE and is able to decrease the synthesis of $\mathrm{NO}^{\bullet}$ [14]. Legend: ADMA: dimethylarginine; NOS: nitric oxide synthase. Adapted from Sanchéz-Araguren et al. [14], Sankaralingam et al. [13], Takacs et al. [97], Rabelo et al. [98], Coman et al. [99], and Morris Jr. [100].

oxidative stress, confirmed by increased expression of $\mathrm{O}_{2}^{\bullet-}$ and peroxynitrite $\left(\mathrm{ONOO}^{-}\right)$; this last one is able to upregulate the LOX-1 expression, suggesting the presence of a feedback mechanism, in which LOX-1 activation induces oxidative stress, which in turn induces LOX-1 $[34,35]$.

\subsection{PE vs. Inflammation and Endothelial Dysfunction. With} the increase of oxidative stress in PE, a concomitant increase of the inflammatory response occurs, through the cytokines' production, such as TNF- $\alpha$ and interleukin- (IL-) 6, which led to a reduction in the anti-inflammatory cytokine production, such as IL-10, with consequent cell damage [14, 36]. Additionally, the process of hypoxia/reperfusion culminates with greater production of ROS, reactive nitrogen species (RNS), and lipid peroxides, while the antioxidant defence is reduced, including superoxide dismutase (SOD), glutathione peroxidase (GPx), and catalase (CAT), leading to an increased systemic oxidative stress condition, also including damaged DNA, low-density lipoprotein (LDL) oxidation, and reduction in melatonin production [37].

In the inflammatory response, there is involvement of genes related to oxidative stress, especially the nuclear factor kappa B (NF- $\kappa \mathrm{B})$, located in the cellular cytoplasm. ROS are able to oxidize the $\mathrm{I} \kappa \mathrm{B}$ kinase (IKK) complex, leading to the release of $\mathrm{NF}-\kappa \mathrm{B}$, which is formed by $\mathrm{p} 50$ and p 65 subunits. As it is a nuclear factor, the NF- $\kappa \mathrm{B}$ molecule enters the cell nucleus and promotes the transcription of several proinflammatory mediators, such as the intracellular adhesion molecule 1 (ICAM-1) and the vascular cell adhesion molecule 1 (VCAM-1), along with proinflammatory cytokines such as IL-6 and TNF- $\alpha$. This process occurs naturally during gestation, but in the $\mathrm{PE}$, its action is exacerbated $[38,39]$ (Figure 2).

In addition to the aforementioned mechanism, during the trophoblastic invasion itself, the decidua, which is the lin- ing of the uterus responsible for the formation of the maternal placenta portion, contains a large number of immune cells, such as macrophages, natural killer (NK) cells, T cells, and regulatory $\mathrm{T}$ cells (Treg), necessary to promote trophoblast migration. In $\mathrm{PE}$, an immunological imbalance is observed, which results in the secretion of proinflammatory cytokines and decrease of Treg cells, this imbalance being responsible for the activation of a chronic inflammatory response in the immune system $[36,40]$.

During the PE, cells of the immune system (T-helper cells) are in high levels and secrete IL-17, which in turn stimulates TNF- $\alpha$ and IL- 6 , which induce the macrophage and neutrophil secretion. Macrophages, neutrophils, and proinflammatory $\mathrm{T}$ cells are also able to convert molecular oxygen into $\mathrm{O}_{2}{ }^{--}$by the phagocyte oxidase system, catalyzed by NADPH oxidase. Once activated, neutrophils can cause placental damage by the release of lysosomal enzymes and ROS. Thus, the activation of NADPH oxidase can be induced by lipoproteins and cytokines, such as proinflammatory interleukins and TNF- $\alpha$ [41].

$\mathrm{PE}$ also results in endothelial dysfunction due to reduced bioavailability of nitric oxide ( $\mathrm{NO}^{\bullet}$ ) and increased production of placental antiangiogenic factors, such as dimethylarginine (ADMA), sEndoglin (soluble endoglin), and Fms-like receptor tyrosine kinase (sFlt-1), a soluble receptor formed by an alternative splicing, leading to the loss of the transmembrane portion of Flt-1, a common receptor for angiogenic factors [42]. $\mathrm{NO}^{\bullet}$ is a vasodilator agent capable of promoting smooth muscle relaxation, regulating endothelial function, platelet aggregation, and the development of muscle cells [43]. Figure 3 shows three pathways capable of explaining the lower bioavailability of $\mathrm{NO}^{\bullet}$ in the PE.

It is noteworthy that pilot studies, such as by Groten et al. [44], where, in a clinical trial, the $\mathrm{NO}^{\bullet}$ donor drug penterythriltetranitrat (PETN) was supplemented to assess its 
TABLE 1: Inflammatory factors involved in the pathophysiology of preeclampsia.

\begin{tabular}{|c|c|}
\hline $\begin{array}{l}\text { Cytokines and transcription } \\
\text { factors }\end{array}$ & Summary of the mechanisms of action \\
\hline IL-1 & $\begin{array}{l}\text { Produced by macrophages and monocytes, as well as nonimmune cells, such as fibroblasts and activated } \\
\text { endothelial cells, during cell injury, infection, invasion, and inflammation. There are two known types: IL-1 } \alpha \\
\text { and IL- } 1 \beta \text {. They act on the same receptors, IL-1RI-considered the active receptor-and IL-1RII, which is } \\
\text { functionally inactive. IL- } 1 \alpha \text { is markedly associated with cell membranes and acts through cellular contacts. } \\
\text { IL- } 1 \beta \text { is synthesized as a precursor protein (pro-IL-1 } \beta \text { ), which is not secreted in the active form, until it is } \\
\text { metabolized by the caspase- } 1 \text { enzyme. IL- } 1 \beta \text { produces systemic inflammation through the activation of } \\
\text { COX-2, with the formation of PGE } 2 \text { in the anterior hypothalamus. It also produces SP, NO }(\text { activating the } \\
\text { enzyme nitric oxide synthase), and endothelial adhesion molecules, such as ICAM-1 and VCAM-1 }[101,102] \text {. }\end{array}$ \\
\hline IL-2 & $\begin{array}{l}\text { Produced mainly by TCD } 4 \text { cells and to a lesser extent by TCD }{ }^{+} \text {cells. It acts through IL-2R } \alpha \text {, IL-2R } \beta \text {, and } \\
\text { IL- } 2 \text { R } \gamma \text { receptors, using the intracellular JAK/STAT pathway to stimulate the growth and proliferation of } \\
\text { T-lymphocytes and B-cells. It also induces the production of other cytokines, such as, for example, IFN- } \gamma \text { and } \\
\text { lymphotoxin- } \alpha \text { which results in the activation of monocytes, neutrophils, and natural killer cells }[102,103] \text {. }\end{array}$ \\
\hline IL-6 & $\begin{array}{l}\text { Produced by macrophages, monocytes, eosinophils, hepatocytes, and glia, with TNF- } \alpha \text { and IL-1 being potent } \\
\text { inducers. It promotes neutrophil maturation and activation, macrophage maturation, and } \\
\text { differentiation/maintenance of T-lymphocytes and natural killer cells. In addition, it activates astrocytes and } \\
\text { microglia and regulates neuropeptide expression after neuronal injury, contributing to its regeneration [101]. }\end{array}$ \\
\hline IL-8 & $\begin{array}{c}\text { IL-8 induces cytoskeletal reorganization, changes in intracellular } \mathrm{Ca}^{2+} \text { levels, integrin activation, granular } \\
\text { protein exocytosis, and respiratory burst [104]. }\end{array}$ \\
\hline TNF- $\alpha$ & $\begin{array}{l}\text { It acts in three different ways: endocrine, autocrine, and paracrine. On the adipocyte, it plays a regulatory role } \\
\text { in relation to the accumulation of body fat, through the increase of lipolysis and inhibition of lipogenesis, from } \\
\text { the blockade of acetyl-CoA synthase action. It has a role in lipid biosynthesis, with a decrease in lipoprotein } \\
\text { lipase expression and a reduction in the synthesis of the glucose transporter to the GLUT-4 membrane, } \\
\text { decreasing the uptake of glucose by the cells mediated by the action of insulin. This reduction of peripheral } \\
\text { sensitivity to insulin causes an increase in hepatic glycogenesis, characterizing a hyperinsulinemic state. In } \\
\text { addition, it has pleiotropic action; i.e., it is capable of influencing different cellular manifestations. It is still } \\
\text { involved in the inflammation process, playing a major role in the cascade of cytokines and stimulating the } \\
\text { synthesis of others }[101,105] .\end{array}$ \\
\hline IL-17 & $\begin{array}{l}\text { This cytokine is predominantly produced by TCD4 lymphocytes with proinflammatory action, leading to the } \\
\text { formation of IL- } 6 \text { and IL-8 (chemokine) and the intercellular adhesion molecule in human fibroblasts. It is } \\
\text { secreted from Th1 and Th17 cells, which are activated during immunological challenges, with cytotoxic } \\
\text { potential to trigger inflammatory responses by recruiting immune cells, which release molecules of oxidative } \\
\text { stress and, consequently, favor endothelial injury }[36,101] \text {. }\end{array}$ \\
\hline $\mathrm{NF}-\kappa \mathrm{B}$ & $\begin{array}{l}\text { Signal-dependent transcription factor. For its activation, several second messenger systems may be required, } \\
\text { thereby determining the induction of transcription of proinflammatory proteins. It can be activated by a } \\
\text { variety of extracellular stimuli, such as proinflammatory cytokines (TNF- } \alpha \text {, IL-1) [106]. }\end{array}$ \\
\hline
\end{tabular}

Legend: $\mathrm{Ca}^{2+}$ : calcium; COX-2: cyclooxygenase-2; GLUT: glucose transporter; ICAM-1: intercellular adhesion molecule 1; IL: interleukin; IFN: interferon; JAK/STAT: Janus family of tyrosinoquinases/transcription factors; NF- $\kappa$ B: nuclear factor kappa B; NO: nitric oxide; PE: preeclampsia; PGE: prostaglandin; SP: substance P; Th cells: T-helper cells; VCAM-1: vascular cell adhesion molecule 1.

prophylactic role in abnormal placentation. Significant improvement in uteroplacental perfusion was observed compared with the placebo (mean $1,26 \pm 0.36$ vs. $1.49 \pm$ $0.44 ; p<0.01)$. In addition, a reduction in the frequency of preterm births, $\mathrm{PE}$, and intrauterine growth restriction was observed, showing the beneficial action of this compound in preventing adverse outcomes of pregnancies in these cases.

Additionally, the endothelial dysfunction that exists in the PE is probably due to hypoxia/reperfusion, which causes oxidative stress that provokes placental production of a large number of antiangiogenic factors, such as sFlt-1 and sEndoglin, and reduction of angiogenic factors vascular endothelial growth factor (VEGF) and placental growth factor (PIGF). Thus, sFlt-1 binds to these circulating molecules and prevents these angiogenic factors from connecting to their common receptors on the cell membrane, causing dysfunction in vascular endothelial repair [45].

Additionally, the endothelial dysfunction also occurs due to an increase in endothelin-1 [46] expression and stimulation of the expression of autoantibodies to the angiotensin II type 1 receptor (AT1-AA). Differently from what occurs in a normal pregnancy, where there is a reduced sensitivity of the endothelium to angiotensin II (Ang II), in pregnant women with PE, due to genetic, immunological, and external factors, there is an excessive sensitivity to Ang II. Thus, AT1 receptor stimulation is also elevated in disease. In addition, women with PE produce autoantibodies to the AT1 receptor (AT1-AA), and the scientific literature suggests that the increase of such antibodies leads to hypertension, from complement activation, proteinuria, and increased levels of antiangiogenic factors [47]. 
TABle 2: Principal biomarkers of oxidative stress and antioxidant compounds involved in the pathophysiology of preeclampsia.

\begin{tabular}{|c|c|}
\hline $\begin{array}{l}\text { Biomarkers of oxidative stress and } \\
\text { antioxidant compounds }\end{array}$ & Definition \\
\hline MDA & $\begin{array}{l}\text { Derived from lipid peroxidation, through the breakdown of endocyclization of polyunsaturated } \\
\text { fatty acids, containing more than two double bonds, such as linoleic, arachidonic, and } \\
\text { docosahexaenoic acid [107]. }\end{array}$ \\
\hline CAT & $\begin{array}{l}\text { It has at its active site the heme group and is attached to a peroxisome, an organelle responsible } \\
\text { for cellular detoxification and oxidation of long chain fatty acids, an inexhaustible source of } \\
\text { organic peroxides, carbonyl products, and singlet oxygen }[107,108] \text {. }\end{array}$ \\
\hline SOD & $\begin{array}{l}\text { The forms detected in humans are the } \mathrm{Cu} / \mathrm{ZnSOD} \text { located in the cytosol (dimeric), lysosomes, } \\
\text { nucleus, and space between the inner and outer membranes of the mitochondria (tetramer), as } \\
\text { well as the MnSOD located in the mitochondria }[107,109] .\end{array}$ \\
\hline GPx & $\begin{array}{l}\text { It is part of the selenoprotein group, with selenium, obtained through the diet linked to } \\
\text { methionine, in foods of plant origin (selenomethionine) and cysteine bound in foods of } \\
\text { animal origin (selenocysteine). This enzyme is capable of reducing peroxides to water or alcohol } \\
{[107,108] .}\end{array}$ \\
\hline $\mathrm{NO}^{\bullet}$ & $\begin{array}{c}\text { It is a marker of reactive nitrogen species, being rapidly metabolized to stable products, i.e., nitrite } \\
\text { and nitrate, in most body fluids, including plasma }[110,111] .\end{array}$ \\
\hline TBARS & It is an indirect marker of lipid peroxidation; it measures the content of MDA $[107,110]$. \\
\hline Vit. C & $\begin{array}{l}\text { It acts as an antioxidant on ROS and RNS, in an aqueous biological environment, resulting in the } \\
\text { formation of the radical anion semidehydroascorbate }\left(\mathrm{Asc}^{\circ-}\right) \text { or ascorbil, which is slightly } \\
\text { reactive }[107,111] .\end{array}$ \\
\hline Vit. E & $\begin{array}{l}\text { The term vitamin } \mathrm{E} \text { is the name of two different families of compounds: tocopherols and } \\
\text { tocotrienols, capable of blocking the lipid peroxidation propagation step of polyunsaturated fatty } \\
\text { acids from membranes and lipoproteins }[111,112] .\end{array}$ \\
\hline
\end{tabular}

Legend: CAT: catalase; Cu/ZnSOD: cooper and zinc superoxide dismutase; GPx: glutathione peroxidase; MDA: malondialdehyde; MnSOD: manganese superoxide dismutase; ROS: reactive oxygen species; RNS: reactive nitrogen species; SOD: superoxide dismutase; TBARS: lipid peroxidation products; vit. C: vitamin C; vit. E: vitamin E.

In this context, Lei et al. [48] evaluated the association between AT1-AA and hypertension using meta-analysis, as well as the prognosis of AT1-AA for hypertensive diseases, and confirmed that elevated levels of AT1-AA in the serum of women are significantly associated with hypertensive disorder, especially PE. In turn, Szpera-Gozdziewicz et al. [49] investigated AT1-AA levels in pregnant women with chronic hypertension, gestational hypertension, and PE compared with healthy pregnant women, showing that women with gestational hypertension and PE presented higher levels than the others.

It is noteworthy that AT1-AA are detectable in animal models of PE and are responsible for elevation of sFlt-1 and soluble endoglin, oxidative stress, and endothelin-1, all of which are enhanced in preeclamptic women [47]. Inhibition of AT1-AA, using the inhibitory peptide n7AAc, prevents the increase in maternal blood pressure and several pathophysiological factors associated with PE in rats, being recognised as a potential therapy for PE [50].

Considering the occurrence of hypoxia/reperfusion in the pathophysiology of $\mathrm{PE}$, which leads to increased oxidative stress, as well as the role of oxidative stress in triggering the inflammatory process observed in the disease, the stimulus that AT1-AA exerts on smooth vascular muscle cells with the consequent activation of NF- $\kappa \mathrm{B}$ generates a vicious cycle between oxidative stress and inflammation $[47,51]$.

Advanced glycation end products (AGEs), resulting from the glycation of proteins or other biomolecules, interact with their receptors (RAGEs) located in a wide variety of tissues.
Such interaction is responsible for triggering the activation of several signaling pathways, culminating with the activation of NF- $\kappa \mathrm{B}$, leading to an inflammatory process. In the $\mathrm{PE}$, considering the ongoing inflammatory process, the possible increase in the AGE/RAGE expression culminates with a higher production of ROS, through the activity of NADPH oxidase, increased stimulation of NF- $\kappa \mathrm{B}$, with consequent release of $\mathrm{O}_{2}{ }^{--}$and its effect on $\mathrm{NO}^{\bullet}$, resulting in the formation $\mathrm{ONOO}^{-}$, which worsens, even more, the existing oxidative stress. Although the data are insufficient to affirm, it is suggested that in PE, RAGEs may be increased, thus bringing more complications to the diseased women $[52,53]$.

Table 1 summarizes the main inflammatory factors involved in the pathophysiology of $\mathrm{PE}$, as well as their forms of action.

\section{PE vs. Oxidative Stress Biomarkers}

Some oxidative stress biomarkers are commonly evaluated in studies involving pregnant women with $\mathrm{PE}$, including antioxidant enzymes (CAT, SOD, and GPx), antioxidant compounds (reduced glutathione (GSH) and vitamins $\mathrm{C}$ and $\mathrm{E}$ ), and products derived from the activity of ROS, mainly through lipid peroxidation (LP) (such as malondialdehyde, MDA) [54] and oxidation of DNA and proteins [55].

Table 2 presents the main oxidative stress markers, enzymes, and antioxidants, involved in the pathophysiology of this disease. 
TABLE 3: Association studies of preeclampsia and its outcomes with levels of oxidative stress biomarkers and antioxidant enzymes, associated or not associated with the analysis of other biomarkers.

\begin{tabular}{|c|c|c|c|c|}
\hline Study & Population & Inclusion/exclusion criteria & $\begin{array}{c}\text { Biomarkers of oxidative } \\
\text { stress/antioxidant enzymes }\end{array}$ & Outcomes \\
\hline $\begin{array}{l}\text { Atamer et al. } \\
(2005)[113]\end{array}$ & $\begin{array}{l}\mathrm{NG}(n=25) \\
\mathrm{CG}(n=28) \\
\mathrm{PE}(n=32)\end{array}$ & $\begin{array}{l}\text { PE women had normal blood } \\
\text { pressure during the first } 20 \text { weeks } \\
\text { of gestation; no previous history } \\
\text { of MD, RD, SAH, or DM; no } \\
\text { history of antioxidant intake and } \\
\text { medication of antihypertensive or } \\
\text { aspirin; and no drugs at the time } \\
\text { of collection of blood samples. } \\
\text { Healthy women (control) did not } \\
\text { suffer from medical conditions } \\
\text { (DM or obesity), and none had a } \\
\text { history of SGA or SAH, in any } \\
\text { previous pregnancy. }\end{array}$ & $\begin{array}{l}\text { MDA-serum } \\
\text { MDA-placental } \\
\text { SOD-erythrocyte } \\
\text { CAT-erythrocyte } \\
\text { GSH-Px-placental } \\
\text { GSH-placental }\end{array}$ & $\begin{array}{c}\text { Significant } \uparrow \text { in serum and } \\
\text { placental MDA levels in PE } \\
\text { pregnant women, and a } \downarrow \text { in } \\
\text { GSH-Px and placental GSH } \\
\text { levels. }\end{array}$ \\
\hline $\begin{array}{l}\text { Aydin et al. (2004) } \\
\text { [114] }\end{array}$ & $\begin{array}{l}\mathrm{NT}(n=34) \\
\mathrm{PE}(n=35)\end{array}$ & $\begin{array}{l}\text { Women not in labor, without } \\
\text { ruptured membranes, neither } \\
\text { multiple pregnancy nor medical } \\
\text { complications, including } \\
\text { autoimmune disorders, DM, } \\
\text { inflammatory conditions, and no } \\
\text { cases of SAH with superimposed } \\
\text { PE. The NT were matched with } \\
\text { those with PE for maternal age, } \\
\text { gestational age at delivery, and } \\
\text { gestational age at blood sampling. }\end{array}$ & $\begin{array}{l}\text { MDA-plasma } \\
\text { SOD-plasma } \\
\text { NO-plasma }\end{array}$ & $\begin{array}{l}\text { Significant } \uparrow \text { in plasma MDA } \\
\text { levels with increases in diastolic } \\
\text { blood pressure }(p<0.001) \text {. In } \\
\text { addition, SOD and NO levels } \\
\text { were significantly } \downarrow \text { with even } \\
\text { greater reduction with } \uparrow \text { diastolic } \\
\text { blood pressure. }\end{array}$ \\
\hline $\begin{array}{l}\text { Yoneyama et al. } \\
(2002)[115]\end{array}$ & $\begin{array}{l}\mathrm{NT}(n=26) \\
\mathrm{PE}(n=26)\end{array}$ & $\begin{array}{l}\text { PE women had normal blood } \\
\text { pressure, during the first } 20 \text { weeks } \\
\text { of gestation; no previous history } \\
\text { of CD, primary SAH, connective } \\
\text { tissue disease, DM, or RD; no } \\
\text { history of antioxidant intake and } \\
\text { medication of antihypertensives } \\
\text { or aspirin; well-established } \\
\text { gestational age; no fetal structural } \\
\text { anomaly; normal response to } \\
\text { GTT; and no evidence of recent } \\
\text { infection. NT matched for } \\
\text { maternal age, parity, and } \\
\text { gestational age. }\end{array}$ & $\begin{array}{l}\text { MDA-plasma } \\
\text { ADA-plasma }\end{array}$ & $\begin{array}{c}\text { Significantly } \uparrow \text { levels of MDA and } \\
\text { ADA in PE }(p<0.05) .\end{array}$ \\
\hline $\begin{array}{l}\text { Orhan et al. (2003) } \\
{[116]}\end{array}$ & $\begin{array}{c}\mathrm{NT}(n=16) \\
\mathrm{PE}(n=9) \\
\mathrm{GDM} \\
(n=3)\end{array}$ & $\begin{array}{l}\text { Well-defined diagnosis of the } \\
\text { diseases (PE and GDM) and } \\
\text { healthy pregnant women in the } \\
\text { NT group. }\end{array}$ & $\begin{array}{c}\text { In plasma and erythrocytes } \\
\text { TBARS } \\
\text { GPx-Se } \\
\text { GSH-Px } \\
\text { CAT } \\
\end{array}$ & $\begin{array}{c}\text { GPx-Se activity significantly } \uparrow \text { in } \\
\text { pregnancy with insulin- } \\
\text { dependent PE and GDM. In } \\
\text { addition, simultaneous } \uparrow \text { in } \\
\text { plasma TBARS levels. } \\
\end{array}$ \\
\hline $\begin{array}{l}\text { Hubel et al. (1996) } \\
\text { [117] }\end{array}$ & $\begin{array}{l}\mathrm{PE}(n=8) \\
\mathrm{NT}(n=9)\end{array}$ & $\begin{array}{l}\text { NT women without proteinuria } \\
\text { or hyperuricemia. } \\
\text { Exclusion criteria: patients with } \\
\text { cigarette or illicit drug use, SAH, } \\
\text { RD, or MD or previous history of } \\
\text { lipid disorders. } \\
\end{array}$ & $\begin{array}{l}\text { Predelivery and postpartum: } \\
\text { MDA-serum }\end{array}$ & $\begin{array}{l}\text { The prepartum MDA levels were } \\
50 \% \uparrow \text { in women with PE; } \downarrow \text { in the } \\
\text { postpartum period. }\end{array}$ \\
\hline $\begin{array}{l}\text { Serdar et al. (2003) } \\
\text { [118] }\end{array}$ & $\begin{array}{c}\text { Mild PE } \\
(n=30) \\
\text { Severe PE } \\
(n=30) \\
\text { NT }(n=50)\end{array}$ & $\begin{array}{l}\text { None of the patients had } \\
\text { preexisting SAH or RD, hepatic, } \\
\text { or hematologic diseases and were } \\
\text { receiving any medication or } \\
\text { vitamin supplementation until } \\
\text { the study samples were taken. } \\
\text { The NT had no signs of }\end{array}$ & $\begin{array}{c}\text { In serum, placental and decidual } \\
\text { Lipid peroxides } \\
\text { Carbonylated proteins } \\
\text { Vit. E } \\
\text { Carotenoids }\end{array}$ & $\begin{array}{l}\text { Lipid peroxides and carbonylated } \\
\text { proteins significantly } \uparrow \text { in the } \\
\text { serum, placenta, and basal } \\
\text { decidua, as well as vit. E and } \\
\text { serum carotenoids were } \downarrow \text { in } \\
\text { severe PE women, compared to } \\
\text { those with mild PE and NT. }\end{array}$ \\
\hline
\end{tabular}


TABle 3: Continued.

\begin{tabular}{|c|c|c|c|c|}
\hline Study & Population & Inclusion/exclusion criteria & $\begin{array}{l}\text { Biomarkers of oxidative } \\
\text { stress/antioxidant enzymes }\end{array}$ & Outcomes \\
\hline & & $\begin{array}{c}\text { pregnancy complication, and all } \\
\text { gave birth to healthy infants } \\
\text { between } 38 \text { and } 40 \text { weeks of } \\
\text { gestation. }\end{array}$ & & $\begin{array}{l}\text { There was also a significant } \\
\text { correlation between diastolic } \\
\text { blood pressure and peroxylipids } \\
\text { in the blood, placenta, and } \\
\text { deciduous and serum } \\
\text { carbonylated proteins. }\end{array}$ \\
\hline
\end{tabular}

\begin{tabular}{|c|c|c|c|}
\hline $\begin{array}{l}\text { Siddiqui et al. } \\
\text { (2013) [119] }\end{array}$ & $\begin{array}{l}\text { PE }(n=40) \\
\text { CG }(n=80)\end{array}$ & $\begin{array}{l}\text { Women were not in labor, } \\
\text { without multiple pregnancies, } \\
\text { and had neither ruptured } \\
\text { membranes nor development of } \\
\text { any simultaneous medical } \\
\text { complications previously or } \\
\text { during pregnancy, such as DM or } \\
\text { inflammatory diseases. The CG } \\
\text { did not exhibit any of the } \\
\text { exclusion criteria. No vitamin } \\
\text { supplements or aspirin was } \\
\text { prescribed to the cases or controls } \\
\text { in the month before their } \\
\text { enrollment in the study. }\end{array}$ & $\begin{array}{l}\text { MDA-serum } \\
\text { Vit. E serum } \\
\text { Total serum GS }\end{array}$ \\
\hline $\begin{array}{l}\text { Sahay et al. (2015) } \\
\text { [120] }\end{array}$ & $\begin{array}{c}\text { NT }(n=35) \\
\text { PE-PT } \\
(n=11) \\
\text { PE-PPT } \\
(n=14)\end{array}$ & $\begin{array}{l}\text { Inclusion criteria: individuals } \\
\text { aged } 18-35 \text { years with a singleton } \\
\text { pregnancy. } \\
\text { Exclusion criteria: any other } \\
\text { pregnancy complication (i.e., } \\
\text { SAH, type } 1 \text { or type } 2 \mathrm{DM} \text {, seizure } \\
\text { disorder, RD, or LD), smoking, } \\
\text { and drug or alcohol use. NT } \\
\text { women aged } 18-35 \text { years, with a } \\
\text { singleton pregnancy delivered at } \\
\text { term and no medical or obstetric } \\
\text { complications. }\end{array}$ & $\begin{array}{c}\text { In placenta } \\
\text { MDA } \\
\text { GPx } \\
\text { CAT }\end{array}$ \\
\hline
\end{tabular}

Markers of oxidative stress, including serum MDA, total $\mathrm{GSH}$, and vit. E, and they were significantly $\neq$ in both groups, with $\uparrow$ levels of MDA, as well as $\downarrow$ levels of vit. E and total GSH, in women with $\mathrm{PE}$.

\begin{tabular}{|c|c|c|c|c|}
\hline & & & & group $(p=0.033)$ \\
\hline $\begin{array}{l}\text { Yuvaci et al. (2016) } \\
\text { [121] }\end{array}$ & $\begin{array}{c}\text { Severe PE } \\
(n=32) \\
\text { Light PE } \\
(n=30) \\
\text { CG }(n=37)\end{array}$ & $\begin{array}{l}\text { Inclusion criteria: age range of } \\
\text { above } 18 \text { years and below } 40 \text { years } \\
\text { and with a single live fetus in } \\
\text { gestation at week } 24 \text { and above. } \\
\text { CG had patients without any } \\
\text { systemic disease. } \\
\text { Exclusion criteria: history of PE } \\
\text { in previous pregnancies, chronic } \\
\text { disease, and drug use affecting } \\
\text { renal and liver functions, SAH, } \\
\text { GDM, type I or type II DM, } \\
\text { connective tissue disease, RD and } \\
\text { LD, hyper/hypothyroidism, } \\
\text { hematologic disease, another } \\
\text { reason for convulsions, a baby } \\
\text { with abnormalities, multiple } \\
\text { pregnancies, and who are found } \\
\text { to have infection in the spot } \\
\text { urinalysis. }\end{array}$ & Total thyroid-serum & $\begin{array}{c}\text { Serum thiol levels were } \\
\text { significantly } \downarrow \text { in pregnant } \\
\text { women with severe PE compared } \\
\text { to those with mild PE and CG. }\end{array}$ \\
\hline
\end{tabular}


TABLE 3: Continued.

\begin{tabular}{|c|c|c|c|c|}
\hline Study & Population & Inclusion/exclusion criteria & $\begin{array}{l}\text { Biomarkers of oxidative } \\
\text { stress/antioxidant enzymes }\end{array}$ & Outcomes \\
\hline $\begin{array}{l}\text { Lucca et al. (2016) } \\
{[122]}\end{array}$ & $\begin{array}{l}\text { Severe PE } \\
(n=3) \\
\text { Light PE } \\
(n=25) \\
\text { CG }(n=30)\end{array}$ & $\begin{array}{l}\text { Inclusion criteria: all pregnant } \\
\text { women were in the } 3^{\text {rd }} \text { trimester } \\
\text { of pregnancy and were in the } \\
\text { same age group. } \\
\text { Exclusion criteria: pregnant } \\
\text { women with chronic diseases, } \\
\text { infectious diseases, cancer, } \\
\text { thyroid dysfunction, or any other } \\
\text { disease, as well as smokers, } \\
\text { drinkers, or anyone using any } \\
\text { kind of medication, except for } \\
\text { pregnant women, with PE who } \\
\text { were using antihypertensives. }\end{array}$ & $\begin{array}{c}\text { Thiol-plasma proteins and } \\
\text { erythrocytes } \\
\text { Vit. C-plasma } \\
\text { CAT-plasma }\end{array}$ & $\begin{array}{l}\text { Levels of TBARS present in } \\
\text { plasma and erythrocytes were } \\
\text { significantly } \uparrow \text { in women with PE, } \\
\text { whereas in thiolate protein } \\
\text { groups, the amounts of vit. C and } \\
\text { CAT were significantly } \downarrow \text { in the } \\
\text { female EP group when compared } \\
\text { to those in the CG. }\end{array}$ \\
\hline
\end{tabular}

Legend: ADA: adenosine deaminase; CAT: catalase; CD: cardiovascular disease; CG: control group; DM: diabetes mellitus; GDM: gestational diabetes mellitus; GPx-Se: glutathione selenium peroxidase; GSH: glutathione; GSH-Px: glutathione peroxidase; GTT: glucose tolerance testing; LD: liver disease; MD: metabolic disorders; MDA: malondialdehyde; NG: not pregnant; NO: nitric oxide; NT: normotensive; PE: preeclampsia; PPT: preterm delivery; PT: birth at term; RD: renal disease; SAH: systemic arterial hypertension; SGA: small for gestational age; TBARS: lipid peroxidation products; vit. C: vitamin C; vit. E: vitamin E; $\uparrow$ : higher; $\downarrow$ : lower; $\neq$ : different.

An extensively evaluated oxidative damage is LP, which plays an important role in the pathophysiology of PE. Oxidized lipids (LP products such as TBARS and F2-isoprostane) affect the functionality of antioxidant enzymes (GPx and SOD) as well as nonenzymatic antioxidants (vitamins A, C, and E) causing oxidative damage [56].

The relationship of PE and its outcomes with some oxidative stress biomarkers and antioxidant enzymes is summarized in Table 3. The results have shown that women with PE, compared to controls, present higher levels of oxidative stress and lipid peroxidation biomarkers, besides lower levels of antioxidant compounds.

It is worth mentioning that a relevant review on oxidative stress biomarkers was published in 2017 [57], aimed at discussing the detection of these markers (MDA, CAT, SOD, GPx, NO, TBARS, and vitamins $\mathrm{C}$ and $\mathrm{E}$ ) in biological fluids and at highlighting the need for further studies to validate their use in the prediction or diagnosis of pregnancy-related diseases, including PE. The authors concluded that the oxidative stress markers are promising for the identification of some complications of gestation; in addition, each one alone may have limitations, but when associated, they may help in the diagnosis of adverse conditions in pregnancy [57].

\section{PE vs. Inflammatory Biomarkers}

Several studies have reported higher levels of proinflammatory cytokines in the serum and plasma of PE women, compared with those with normal pregnancies [36, 58-60]. Although the literature provides wide and comprehensive reports related to this subject, the present review does not pretend to be exhaustive, considering that the key point of this study is to emphasize the interaction between the factors suggested as being involved in the pathophysiology of PE, and not only the inflammatory process [61] (Table 4). We are reporting only selected inflammatory markers, as there are several other cytokines and chemokines that have been studied in PE. The cytokines more widely studied and with a well-established knowledge of their mechanisms, in relation to $\mathrm{PE}$, were chosen.

Table 4 shows that several studies have been conducted in humans and animals, especially in recent years, in order to clarify the role of inflammatory cytokines in PE. The inclusion or exclusion criteria were added. From these findings, it is clear their involvement in the pathophysiology of the disease and that their levels increase according to the severity of PE. In addition, experimental studies $[40,62,63]$ also show an increase in levels of inflammatory factors in PE, which is associated with endothelial dysfunction, also observed, as well as the protective role of IL-10, when administered in an appropriate dose/time $[64,65]$.

\section{PE vs. Antioxidant Therapy}

The use of supplementation with antioxidant compounds in several clinical and pathological contexts has been widely discussed and performed; however, in the PE, their uses present controversial results both in prevention and in treatment [66].

Table 5 lists the majority of the reported studies on humans, involving oral antioxidant supplementation for the prevention and treatment of PE. The inclusion or exclusion criteria were added. The included studies were carried out with different antioxidant compounds, being the first reported in 2003. It is possible to observe that there is no consensus about the dosages and times of administration of the supplementation, corroborating with controversial findings in relation to the outcomes of pregnancy. However, among 
TABLE 4: Studies associating preeclampsia and its outcomes with levels of inflammatory markers in humans and animals.

\begin{tabular}{|c|c|c|c|}
\hline Study & Population & Inclusion/exclusion criteria & Inflammation biomark \\
\hline $\begin{array}{l}\text { Cackovic et al. (2008) } \\
\text { [58] }\end{array}$ & $\begin{array}{c}\text { Humans: } \\
\text { CG }(n=45) \\
\text { PE }(n=45)\end{array}$ & $\begin{array}{l}\text { Inclusion criteria: CG matched } \\
\text { one to one for maternal and } \\
\text { gestational age at enrollment and } \\
\text { had a pregnancy course } \\
\text { uncomplicated by PE. } \\
\text { Exclusion criteria: preexisting } \\
\text { proteinuria and/or SAH, active } \\
\text { labor, clinical symptoms } \\
\text { suggestive of viral or bacterial } \\
\text { infection, known or suspected } \\
\text { congenital malformation, and } \\
\text { isolated IUGR. }\end{array}$ & $\begin{array}{l}\text { Serum and urinary } \\
\text { TNF- } \alpha\end{array}$ \\
\hline
\end{tabular}

Sandrim et al. (2008)

[59]

Humans:

$\mathrm{CG}(n=58)$

GDH $(n=56)$

$\mathrm{PE}(n=45)$
Inclusion criteria: women without preexisting SAH. Exclusion criteria: twin or multiple pregnancies or any evidence of previous medical illness.
Nitrite-serum

A $\uparrow$ serum concentration was observed in PE vs. CG

as well as sFlt-1. On the other hand, urinary levels of TNF- $\alpha$ were $\downarrow$ in PE and did not correlate with the degree of proteinuria, when compared to CG. In addition, in PE, the fractionated excretion of TNF- $\alpha$ was significantly $\downarrow$ despite the existence of proteinuria. Thus, the $\downarrow$ renal excretion of TNF- $\alpha$ may contribute to the exacerbated inflammatory response, observed in the pathophysiology of the disease, considering that there is an accumulation of this biomarker in the body.

Serum levels of nitrite were $\downarrow$ in GDH and PE women vs. CG $(-36 \%$ and $-58 \%$, respectively, both $p<0.05)$. Even $\downarrow$ serum concentrations of sEndoglin and sFlt- 1 were observed in

PE women $v s$. GDH and

CG. Thus, impairment in the formation of $\mathrm{NO}^{\bullet}$ in $\mathrm{PE}$ was suggested.

The results indicated a $\uparrow$ mean arterial pressure and

AT1-AA in animals receiving chronic infusion of IL-6, which was abolished in those treated previously with the antihypertensive agent (losartan: angiotensin receptor antagonists). Thus, these data showed that IL-6 stimulates AT1-AA and that activation of AT1R mediates IL-6-induced hypertension during pregnancy.

Animals exposed to hypoxia tended to develop the characteristic symptoms of $\mathrm{PE}$, such as placental injury, proteinuria, hypertension, and systemic symptoms. In addition, there was an $\uparrow$ in the expression of antiangiogenic factors, such as sFlt-1. However, after IL-10 administration, the 
TABLe 4: Continued.

\begin{tabular}{|c|c|c|c|c|}
\hline Study & Population & Inclusion/exclusion criteria & Inflammation biomarkers & Outcomes \\
\hline & & & & $\begin{array}{l}\text { protective role of this } \\
\text { cytokine was observed, in } \\
\text { relation to the development } \\
\text { of symptoms and disease } \\
\text { progression, indicating an } \\
\text { IL-10 protective role in PE. }\end{array}$ \\
\hline $\begin{array}{l}\text { Dhillion et al. (2012) } \\
\text { [40] }\end{array}$ & $\begin{array}{c}\text { Experimental: } \\
\text { Rats } \\
\text { NP }(n=20) \\
\text { NP+IL-17 }(n=12) \\
\text { NP+tempol }(n=7) \\
\text { NP+IL-17+tempol } \\
\quad(n=11)\end{array}$ & - & IL-17 & $\begin{array}{c}\text { IL-17 causes placental } \\
\text { oxidative stress, which } \\
\text { serves as stimulus } \\
\text { modulating AT1-AAs that } \\
\text { may play an important role } \\
\text { in mediating IL-17-induced } \\
\text { hypertension during } \\
\text { pregnancy. }\end{array}$ \\
\hline
\end{tabular}

Chronic infusion of TNF- $\alpha$ had no significant effect on arterial pressure or renal preproendothelin levels in

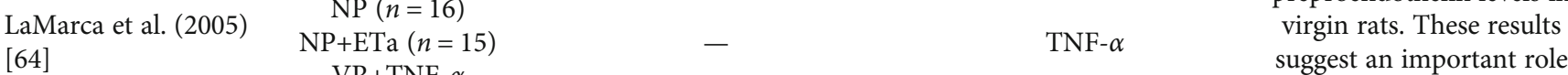
[64]

$$
\begin{gathered}
\text { VR+TNF- } \alpha \\
(n=12) \\
\text { CG }(n=11)
\end{gathered}
$$

for endothelin in mediating

TNF- $\alpha$-induced hypertension in pregnant rats.

Inclusion criteria: CG had all women in the $3^{\text {rd }}$ trimester of pregnancy and none of them

Sahin et al. (2015) [123]

Humans:
PE $(n=41)$
CG $(n=80)$

Humans:

CG $(n=80)$ developed PE or other pregnancy complications.

Exclusion criteria: women in labour, multiple pregnancies, ruptured membranes, or medical

history of SAH and DM.
An enhanced inflammatory response was observed in severe PE women demonstrated by $\uparrow$ levels of IL-8 and decreased levels of IL-10. However, the intensity of platelet activation did not correlate directly with the change in plasma levels of IL-8 and IL-10 in PE women.

Inclusion criteria: pregnant women in the $3^{\text {rd }}$ trimester with $\mathrm{PE}$ or with an uncomplicated Humans: pregnancy.

Silva et al. (2013) [65] PE $(n=50)$ CG $(n=50)$

Exclusion criteria: smokers and had systemic diseases and/or associated genital tract diseases (DM, SAH, RD, TD, LE, UI, and cervical or vaginal inflammation).

Inclusion criteria: all women were Caucasian and lived in the same geographic area. CG was in the early follicular phase of their menstrual cycle, and none of them received hormonal contraception.

Molvarec et al. (2015) [124]

Humans:
PE $(n=59)$
CG $(n=60)$

Humans:

CG $(n=60)$

Exclusion criteria: multifetal
The study reinforces the hypothesis that there is an immune dysfunction in $\mathrm{PE}$, with an $\uparrow$ in the production of proinflammatory

cytokines IL- 6 and TNF- $\alpha$, and a compensatory increase in IL-10. gestation, SAH, DM, AID, angiopathy, $\mathrm{RD}$, maternal or fetal infection, and fetal congenital anomaly. None of them was in active labor, and none had
The serum IL-17 levels are $\uparrow$ in $\mathrm{PE}$, which may contribute to the development of the excessive systemic inflammatory response characteristic of the maternal syndrome of the disease. 
TABLe 4: Continued.

\begin{tabular}{|c|c|c|c|c|}
\hline Study & Population & Inclusion/exclusion criteria & Inflammation biomarkers & Outcomes \\
\hline & & $\begin{array}{l}\text { rupture of the amniotic } \\
\text { membranes. Pregnant women } \\
\text { with eclampsia or HELLP } \\
\text { syndrome. }\end{array}$ & & \\
\hline
\end{tabular}

\begin{tabular}{|c|c|c|}
\hline Sun et al. (2016) [125] & $\begin{array}{c}\text { Humans: } \\
\text { PE }(n=160) \\
\text { CG }(n=140)\end{array}$ & $\begin{array}{l}\text { All women in the } 3^{\text {rd }} \text { trimester of } \\
\text { pregnancy. Single pregnancy; } \\
\text { cesarean section; same types of } \\
\text { anesthesia; no previous medical } \\
\text { history of SAH, CD, RD, DM, } \\
\text { hyperthyroidism, or other } \\
\text { complications that may lead to } \\
\text { vascular disorders and hypoxic } \\
\text { changes; and no infectious } \\
\text { diseases. }\end{array}$ \\
\hline
\end{tabular}

The IL-8 expression had positive association with the severity of PE. Results from enzyme-linked immunosorbent assay showed that the concentration of serum IL-8 in PE patients $(180.27 \pm 5.81 \mathrm{ng} / \mathrm{L})$ was significantly higher than that in healthy controls

$(41.57 \pm 5.67 \mathrm{ng} / \mathrm{L})$.

Patients with severe PE had even higher serum IL-8 levels.

Inclusion criteria: primiparous women without previous history of SAH or obstetric and medical complications. In CG, women with an uncomplicated

Humans:

Ribeiro et al. (2017) [126] Early PE $(n=20)$

Late PE $(n=20)$ CG $(n=20)$ pregnancy and matched for gestational age with the PE group.

Exclusion criteria: multiple gestation, prior PE, illicit drug use, and medical conditions such as DM, cancer, $\mathrm{SAH}$, acute infectious diseases, CD, AID, RD, and LD. IL 4, IL-6, IL-17,IL-22, and
TNF- $\alpha$
Endogenous plasma levels of IL-6, IL-17, and TNF- $\alpha$ were significantly $\uparrow$ in the early-onset PE group than in the late-onset $\mathrm{PE}$ and normotensive groups, whereas IL-4 (Th2 profile) and IL-22 (Th17 profile) were not significantly different between the studied groups.

\begin{tabular}{|c|c|c|c|c|}
\hline $\begin{array}{l}\text { Aggarwal et al. (2019) } \\
\text { [127] }\end{array}$ & $\begin{array}{c}\text { Humans: } \\
\text { PE+CG ( } n=194) \\
\text { Mixed groups: } \\
\text { I }(n=55) 28-36 \\
\text { weeks } \\
\text { II }(n=139) 37 \\
\text { weeks onwards }\end{array}$ & $\begin{array}{l}\text { PE diagnosis and CG not having } \\
\text { any history of pregnancy-related } \\
\text { complications, DM or any other } \\
\text { chronic medical illness, vaginal } \\
\text { bleeding throughout pregnancy, } \\
\text { along with no evidence of } \\
\text { congenital abnormalities, } \\
\text { tuberculosis, and not having } \\
\text { habits like tobacco, alcohol, and } \\
\text { smoking. }\end{array}$ & $\begin{array}{l}\text { TNF- } \alpha, \text { IL-6, IL-4, } \\
\text { and IL-10 }\end{array}$ & $\begin{array}{l}\text { The levels of TNF- } \alpha \text { and } \\
\text { IL- } 6 \text { were significantly } \uparrow \text { in } \\
\text { PE cases, while the IL- } 4 \text { and } \\
\text { IL-10 were downregulated } \\
\text { in comparison to control. In } \\
\text { addition, a negative } \\
\text { correlation was also } \\
\text { observed between the two in } \\
\text { PE }(p=0.0001) .\end{array}$ \\
\hline $\begin{array}{l}\text { Peixoto et al. (2016) } \\
\text { [128] }\end{array}$ & $\begin{array}{c}\text { Humans: } \\
\text { CG }(n=30) \\
\text { PE }(n=16)\end{array}$ & $\begin{array}{l}\text { Inclusion criteria: women with } \\
\text { PE, eclampsia, and HELLP } \\
\text { syndrome, irrespective of } \\
\text { gestational age and indication for } \\
\text { delivery. The CG included } \\
\text { pregnant women without } \\
\text { complications, according to } \\
\text { clinical and laboratory } \\
\text { parameters. } \\
\text { Exclusion criteria: pregnant } \\
\text { women with gestational SAH, } \\
\text { chronic SAH, PE superimposed } \\
\text { on SAH, and patients who have } \\
\text { had spontaneous premature } \\
\text { delivery and PPRM. }\end{array}$ & $\begin{array}{l}\text { IL- } 4, \text { IL-10, IL-13, TNF- } \alpha \text {, } \\
\text { and IFN- } \gamma\end{array}$ & $\begin{array}{c}\text { Patients with PE presented } \\
\text { significantly } \downarrow \text { placental } \\
\text { levels of IL-10 and IL-13 } \\
\text { than the CG. } \\
\text { IL- } 4 \text {, TNF- } \alpha \text {, and IFN- } \gamma \\
\text { levels were similar on the } \\
\text { two groups. } \\
\uparrow \text { inflammatory balance was } \\
\text { observed in patients with } \\
\text { PE } v s \text {. normal. }\end{array}$ \\
\hline
\end{tabular}


TABLe 4: Continued.

\begin{tabular}{|c|c|c|c|c|}
\hline Study & Population & Inclusion/exclusion criteria & Inflammation biomarkers & Outcomes \\
\hline $\begin{array}{l}\text { Kalantar et al. (2013) } \\
\text { [129] }\end{array}$ & $\begin{array}{c}\text { Humans: } \\
\text { CG }(n=40) \\
\text { PE }(n=44)\end{array}$ & $\begin{array}{l}\text { Inclusion criteria: CG consisted } \\
\text { of healthy women with } \\
\text { uncomplicated pregnancy. They } \\
\text { did not receive any special drug } \\
\text { during the pregnancy except } \\
\text { routine supplements. } \\
\text { Exclusion criteria: pregnant } \\
\text { women with pregestational DM } \\
\text { and SAH. }\end{array}$ & TNF- $\alpha$, IL-15, and IL-10 & $\begin{array}{l}\text { For PE women, significantly } \\
\uparrow \text { serum levels of TNF- } \alpha \\
\text { and IL-15, in comparison } \\
\text { with CG. Conversely, the } \\
\text { serum levels of IL-10 in CG } \\
\text { were significantly } \uparrow v s \text {. PE. }\end{array}$ \\
\hline
\end{tabular}

Inclusion criteria: PE developed during the $3^{\text {rd }}$ trimester of pregnancy. CG with no evidence of SAH or proteinuria during the current pregnancy and had no sign of gestational complication or fetal distress. Similar maternal Kalinderis et al. (2011) [130]

Humans: CG $(n=30)$ $\mathrm{PE}(n=30)$ age, gestational age and BMI to PE women.

IL- $1 \beta$, IL-6

Serum IL-6 and IL- $1 \beta$ levels were significantly $\uparrow$ in women with PE vs. CG.

Exclusion criteria: women with multiple gestation, DM, SAH, infectious diseases in pregnancy, PPRM, active labour, polyhydramnios, and signs of other concurrent medical complications.

\begin{tabular}{|c|c|c|c|c|}
\hline $\begin{array}{l}\text { El-Kabarity and } \\
\text { Naquib (2011) [131] }\end{array}$ & $\begin{array}{c}\text { Humans: } \\
\text { CG }(n=60) \\
\operatorname{PE}(n=120)\end{array}$ & $\begin{array}{l}\text { All pregnant women were in their } \\
3^{\text {rd }} \text { trimester, and CG were } \\
\text { demographically matched to the } \\
\text { PE women. }\end{array}$ & IL-12, IL-18 & $\begin{array}{c}\text { IL- } 18 \text { was significantly } \uparrow \text { in } \\
\text { women with PE than in CG. } \\
\text { IL- } 12 \text { was not significantly } \uparrow \\
\text { in mild PE but significantly } \\
\uparrow \text { in severe cases. }\end{array}$ \\
\hline $\begin{array}{l}\text { Sharma et al. (2011) } \\
\text { [132] }\end{array}$ & $\begin{array}{c}\text { Humans: } \\
\text { CG }(n=200) \\
\text { PE }(n=300)\end{array}$ & $\begin{array}{l}\text { Inclusion criteria: women in both } \\
\text { the groups were primiparous, and } \\
\text { the gestational age was between } \\
25 \text { and } 36 \text { weeks. All the selected } \\
\text { women were nonsmokers and did } \\
\text { not suffer from any active } \\
\text { infectious process. } \\
\text { Exclusion criteria: women } \\
\text { associated with multiple } \\
\text { pregnancies, DM, Rh- } \\
\text { incompatibility, bleeding } \\
\text { disorders, systemic LE, } \\
\text { hydramnios, and pregnancies } \\
\text { complicated by fetal } \\
\text { abnormalities; pregnant women } \\
\text { on any medication or chronic } \\
\text { disorders, and metabolic } \\
\text { disorders. }\end{array}$ & $\begin{array}{l}\text { ET1, IL- } 2, \text { TNF- } \alpha \text {, and } \\
\text { IFN- } \gamma\end{array}$ & $\begin{array}{c}\uparrow \mathrm{ET} 1, \mathrm{IL}-2, \mathrm{TNF}-\alpha \text {, and } \\
\text { IFN- } \gamma \text { in the PE group } v s . \\
\text { CG. }\end{array}$ \\
\hline
\end{tabular}

Legend: AID: autoimmune disease; AT1: autoantibody receptor against Ang II type 1; AT1-AA: angiotensin II receptor type 1; BMI: body mass index; CD: cardiovascular disease; CG: control group; DM: diabetes mellitus; ET1: endothelin-1; Eta: endothelin receptor antagonist; GDH: pregnant woman with hypertensive disorder; IFN: interferon; IG: intervention group; IL: interleukin; IUGR: intrauterine growth restriction; LD: liver disease; LE: lupus erythematosus; NP: normal pregnant; NT: normotensive; PE: preeclampsia; PPRM: preterm premature rupture of membranes; RD: renal disease; SAH: systemic arterial hypertension; tempol: 4-hydroxy-2,2,6,6-tetramethylpiperidine- $N$-oxyl; TD: thyroid disorders; TNF- $\alpha$ : tumor necrosis factor alpha; UI: urinary infection; VR: virgin rats; vit. E: vitamin E; sFlt-1: soluble Fms-like receptor tyrosine kinase; $\uparrow:$ higher; $\downarrow$ : lower. 
TABLE 5: Human research involving oral antioxidant supplementation for the prevention and treatment of preeclampsia.

\begin{tabular}{|c|c|c|c|c|}
\hline Study & Antioxidant & Inclusion/exclusion criteria & Dose/time & Outcomes \\
\hline $\begin{array}{l}\text { Banerjee et al. } \\
(2009)[67]\end{array}$ & Lycopene & $\begin{array}{l}\text { Inclusion criteria: primiparous } \\
\text { women with singleton pregnancy } \\
\text { between } 12 \text { and } 20 \text { weeks of } \\
\text { gestation, with the absence of any } \\
\text { medical problems, such as } \mathrm{CH} \text {, } \\
\text { RD, gross obesity, diabetes, } \\
\text { thrombophilia, CD, or connective } \\
\text { tissue disease. } \\
\text { Criteria to PE: blood pressure } \\
\text { consistently more than } \\
\text { 140/90 mmHg in a previously } \\
\text { normotensive woman } \\
\text { accompanied with newly onset } \\
\text { proteinuria of more than } \\
300 \text { mg/24h urine collection or, } \\
>1+\text { on clean catch dipstick in a } \\
\text { random urine sample in the } \\
\text { absence of urinary infection. }\end{array}$ & $\begin{array}{c}2 \mathrm{mg} \\
12-20 \text { weeks until delivery }\end{array}$ & $\begin{array}{c}\text { The supplemented group: } \uparrow \text { in the } \\
\text { incidence of adverse effects of } \\
\text { preterm birth and LBW. }\end{array}$ \\
\hline $\begin{array}{l}\text { Pulido et al. } \\
\text { (2016) [73] }\end{array}$ & $L$-Arginine & $\begin{array}{l}\text { Inclusion criteria: women who } \\
\text { had high-risk factors for } \\
\text { developing PE (nulliparous, } \\
\text { previous history of PE, CH, and } \\
\text { BMI } \geq 30 \text { ). } \\
\text { Exclusion criteria: patients with } \\
\text { multiple pregnancies or } \\
\text { comorbidities (DM, hepatopathy, } \\
\text { HD, and collagen disease), } \\
\text { alcohol consumption, anti- } \\
\text { inflammatory/antioxidant drug } \\
\text { ingestion, infections, or } \\
\text { concomitant medication. }\end{array}$ & $\begin{array}{c}3 \mathrm{~g} \\
3 \text { weeks during gestation and } 2 \\
\text { weeks postpartum }\end{array}$ & $\begin{array}{l}\text { Maternal blood pressure and } \\
\text { prematurity rates were } \\
\text { significantly } \downarrow \text { in the intervention } \\
\text { group, while birth weight was } \uparrow \text {. } \\
\text { The Apgar score }<7 \text { to } 5 \text { min was } \\
\text { not } \neq \text { between the groups, and } \\
\text { there was no neonatal or } \\
\text { maternal death. }\end{array}$ \\
\hline
\end{tabular}

Inclusion criteria: the patients were normotensive during the $1^{\text {st }}$ trimester and had no history of $\mathrm{SAH}$. None of the women had a history of PE or other factors that cause IUGR.

Exclusion criteria: women who had a history of being smokers,

Valdivia-Silva et al. (2009) [74]
L-Arginine coronary $\mathrm{HD}, \mathrm{RD}$ and/or DM, prophylactic treatments with aspirin or fetal malformations detected by ultrasonography, and the presence of some complication that would require an emergency delivery that has not allowed the treatment to continue for at least 3 weeks.
The risk of IUGR was $5 \mathrm{x} \uparrow$ in infants born to mothers with PE without $L$-arginine therapy and twice as often in babies born to mothers with $\mathrm{PE}$ in the intervention group. The fetal biophysical profile and the Apgar score were significantly more favorable in the intervention

group.
$3 \mathrm{~g}$
20 weeks until delivery 
TABle 5: Continued.

\begin{tabular}{|c|c|c|c|c|}
\hline Study & Antioxidant & Inclusion/exclusion criteria & Dose/time & Outcomes \\
\hline $\begin{array}{l}\text { Teran et al. } \\
(2009)[71]\end{array}$ & $\begin{array}{l}\text { Coenzyme } \\
\text { Q10 }\end{array}$ & $\begin{array}{l}\text { Inclusion criteria: women } \\
\text { between } 16 \text { and } 20 \text { weeks of } \\
\text { pregnancy (established by date of } \\
\text { last menstrual period and } \\
\text { confirmed by ultrasound), not } \\
\text { currently taking medication, and } \\
\text { with no known medical disorders. } \\
\text { Exclusion criteria: women who } \\
\text { were taking vitamin supplements. }\end{array}$ & $\begin{array}{c}200 \mathrm{mg} \\
20 \text { weeks until delivery }\end{array}$ & $\begin{array}{l}\text { There were no } \neq \text { between the } \\
\text { groups in the incidence of LBW } \\
\text { and mean birth weight. There was } \\
\text { no perinatal mortality. Only } 2 \\
\text { pregnancies resulted in preterm } \\
\text { birth and both were in the } \\
\text { placebo group. }\end{array}$ \\
\hline $\begin{array}{l}\text { Tara et al. (2010) } \\
\text { [69] }\end{array}$ & Selenium & $\begin{array}{l}\text { Inclusion criteria: gestational age } \\
\text { up to } 12 \text { weeks, and with no } \\
\text { indications for termination of the } \\
\text { pregnancy. } \\
\text { Exclusion criteria: in use of any } \\
\text { drugs, except routine } \\
\text { supplements of folic acid and } \\
\text { ferrous sulphate, and a prior } \\
\text { history or clinical features of any } \\
\text { medical conditions, including } \\
\text { thyroid disorders, DM, SAH, and } \\
\text { infections. }\end{array}$ & $\begin{array}{c}100 \mu \mathrm{g} \\
1^{\text {st }} \text { trimester until childbirth }\end{array}$ & $\begin{array}{l}\text { Selenium supplementation } \\
\text { significantly } \uparrow \text { serum selenium } \\
\text { concentrations in full-term } \\
\text { newborns. However, there were } \\
\text { no } \neq \text { in systolic and diastolic } \\
\text { blood pressure, total serum } \\
\text { cholesterol and fractions, } \\
\text { triglycerides, and high sensitivity } \\
\text { C-reactive protein between the } \\
\text { groups. }\end{array}$ \\
\hline $\begin{array}{l}\text { Aalami-Harandi } \\
\text { et al. (2014) [70] }\end{array}$ & Allicin & $\begin{array}{l}\text { Pregnant women at risk for PE, } \\
\text { primiparous women, aged } 18-40 \\
\text { years old who were carrying } \\
\text { singleton pregnancy at } 27 \text { weeks } \\
\text { of gestation. }\end{array}$ & $\begin{array}{c}400 \mathrm{mg} \text { garlic } \\
(1 \mathrm{mg} \text { allicin }) \\
27 \text { weeks, for } 9 \text { weeks }\end{array}$ & $\begin{array}{l}\text { Significant protein } \downarrow \text { in C-reactive } \\
\text { protein and a significant } \uparrow \text { in } \\
\text { plasma GSH levels. No significant } \\
\text { effect on serum lipid profiles, } \\
\text { plasma levels of total antioxidant } \\
\text { capacity and pregnancy } \\
\text { outcomes. }\end{array}$ \\
\hline $\begin{array}{l}\text { Motawei et al. } \\
(2016)[72]\end{array}$ & $\begin{array}{l}N \text {-Acetyl- } \\
\text { cysteine }\end{array}$ & $\begin{array}{l}\text { Women with diagnosis of } \mathrm{PE} \text { and } \\
\text { health pregnancy to the control } \\
\text { group. }\end{array}$ & $\begin{array}{l}400 \mathrm{mg} \\
\text { For } 6 \text { weeks }\end{array}$ & $\begin{array}{l}\text { Improvement in pregnancy } \\
\text { outcomes, birth weight, and } \\
\text { Apgar score among intervention } \\
\text { group patients but without } \neq \text { in } \\
\text { the incidence of obstetric } \\
\text { complications and markers of } \\
\text { oxidative stress between the two } \\
\text { groups. }\end{array}$ \\
\hline
\end{tabular}

Inclusion criteria: women who were $120 / 7$ to $196 / 7$ weeks pregnant and diagnosed with nonproteinuric chronic hypertension SAH or a prior history of PE in their most recent pregnancy that progressed beyond 20 weeks of gestation.

Spinnato et al. (2007) [75]
Vits. C and E gestation, allergy to vit. $\mathrm{C}$ or $\mathrm{E}$, requirement for aspirin or anticoagulant medication, 24hour urinary protein $300 \mathrm{mg}$ or more, prepregnancy DM, known fetal anomaly incompatible with life, or prior participation in the study.

Preterm membrane rupture was $\uparrow$ in the intervention group. There was no influence on the

$1000 \mathrm{mg}$ $400 \mathrm{IU}$

12-19 weeks until childbirth or disease development frequency of LBW, small for gestational age, stillbirth, birth measurement, asphyxia or Apgar scores. 
TABle 5: Continued.

\begin{tabular}{|c|c|c|c|c|}
\hline Study & Antioxidant & Inclusion/exclusion criteria & Dose/time & Outcomes \\
\hline $\begin{array}{l}\text { Xu et al. (2010) } \\
\text { [133] }\end{array}$ & Vits. $\mathrm{C}$ and $\mathrm{E}$ & $\begin{array}{l}\text { Inclusion criteria: women } \\
\text { between } 12 \text { and } 18 \text { completed } \\
\text { weeks of pregnancy on the basis } \\
\text { of last menstrual period and } \\
\text { confirmed by early ultrasound } \\
\text { examination. } \\
\text { Exclusion criteria: women who } \\
\text { regularly consumed supplements } \\
200 \text { mg/day for vit. C and/or } \\
50 \text { IU/day for vit. E; women who } \\
\text { took warfarin; women who had } \\
\text { known fetal abnormalities or } \\
\text { known fetal chromosomal or } \\
\text { major malformations in the } \\
\text { current pregnancy; women who } \\
\text { had a history of medical } \\
\text { complications including } \\
\text { endocrine disease, RD with } \\
\text { altered renal function, epilepsy, } \\
\text { any collagen vascular disease, } \\
\text { active and chronic LD, HD, } \\
\text { cancer, or hematologic disorder; } \\
\text { women with repeated } \\
\text { spontaneous abortion (women } \\
\text { with a previous bleeding in the } 1 \text { st } \\
\text { trimester were included if the site } \\
\text { documented a viable fetus at the } \\
\text { time of recruitment); and women } \\
\text { who used an illicit drug during } \\
\text { the current pregnancy. }\end{array}$ & $\begin{array}{c}1000 \mathrm{mg} \\
400 \mathrm{IU} \\
12-18 \text { weeks until delivery }\end{array}$ & $\begin{array}{l}\text { No difference in maternal adverse } \\
\text { outcomes between groups, } \\
\text { including rates of miscarriage, } \\
\text { fetal death, neonatal death, } \\
\text { preterm birth, IUGR, or small for } \\
\text { gestational age. }\end{array}$ \\
\hline $\begin{array}{l}\text { Sharma et al. } \\
(2003)[68]\end{array}$ & Lycopene & $\begin{array}{l}\text { Primiparous women with } \\
\text { gestation between } 16 \text { and } 20 \\
\text { weeks with absence of any } \\
\text { medical complication such as RD, } \\
\text { SAH, HD, DM, or connective } \\
\text { tissue disease. }\end{array}$ & $\begin{array}{c}2 \mathrm{mg} \\
\text { 16-20 weeks until delivery or } \\
\text { development of PE }\end{array}$ & $\begin{array}{c}\text { The mean birth weight was } \uparrow \text { and } \\
\text { there was } \downarrow \text { of IUGR in the } \\
\text { intervention group. }\end{array}$ \\
\hline $\begin{array}{l}\text { Roberts et al. } \\
(2010) \text { [134] }\end{array}$ & Vits. $\mathrm{C}$ and $\mathrm{E}$ & $\begin{array}{l}\text { Inclusion criteria: pregnant } \\
\text { women who had a singleton fetus } \\
\text { with a gestational age of less than } \\
16 \text { weeks } 0 \text { days at the time of } \\
\text { screening. Gestational age at } \\
\text { randomization was between } 9 \\
\text { weeks } 0 \text { days and } 16 \text { weeks } 6 \text { days. } \\
\text { Women were eligible for } \\
\text { inclusion if they had not had a } \\
\text { previous pregnancy that lasted } \\
\text { beyond } 19 \text { weeks } 6 \text { days. } \\
\text { Gestational age was determined } \\
\text { before randomization with the } \\
\text { use of a previously described } \\
\text { algorithm that took into account } \\
\text { the date of the last menstrual } \\
\text { period (if reliable information } \\
\text { was available) and results of the }\end{array}$ & $\begin{array}{c}\text { 9 } \\
1000 \mathrm{mg} \\
400 \mathrm{IU} \\
9-16 \text { weeks, until delivery }\end{array}$ & $\begin{array}{l}\text { Vitamins } \mathrm{C} \text { and } \mathrm{E} \text { did not reduce } \\
\text { adverse maternal or perinatal } \\
\text { outcomes in women at high risk. }\end{array}$ \\
\hline
\end{tabular}


TABLe 5: Continued.

\begin{tabular}{|c|c|c|c|c|}
\hline Study & Antioxidant & Inclusion/exclusion criteria & Dose/time & Outcomes \\
\hline & & $\begin{array}{l}\text { earliest ultrasound examination. } \\
\text { Exclusion criteria: women with } \\
\text { elevated systolic blood pressure } \\
\text { ( } 135 \mathrm{mmHg} \text { or higher), elevated } \\
\text { diastolic blood pressure } \\
\text { ( } 85 \mathrm{mmHg} \text { or higher), or } \\
\text { proteinuria ( } 300 \mathrm{mg} \text { of protein or } \\
\text { more, as measured in a } 24 \text {-hour } \\
\text { urine sample, or a urine-dipstick } \\
\text { result of } 1+\text { or higher for protein), } \\
\text { were taking or had taken } \\
\text { antihypertensive medication, or } \\
\text { were taking more than } 150 \text { mg of } \\
\text { vitamin C or more than } 75 \text { IU of } \\
\text { vit. E daily. DM that was present } \\
\text { before the pregnancy, treatment } \\
\text { with antiplatelet drugs or } \\
\text { nonsteroidal anti-inflammatory } \\
\text { agents, uterine bleeding within } \\
\text { the week before recruitment, } \\
\text { uterine malformation, serious } \\
\text { medical condition, known fetal } \\
\text { anomaly or aneuploidy, in vitro } \\
\text { fertilization resulting in the } \\
\text { current pregnancy, or abuse of } \\
\text { illicit drugs or alcohol. }\end{array}$ & & \\
\hline
\end{tabular}

Legend: BMI: body mass index; DM: diabetes mellitus; GSH: reduced glutathione; HD: hearth disease; IUGR: intrauterine growth restriction; LBW: low birth weight; LD: liver disease; PE: preeclampsia; $\uparrow$ : higher; $\downarrow$ : lower; \#: difference; RD: renal disease; SAH: systemic arterial hypertension; vits.: vitamins.

the natural antioxidants tested in PE, lycopene appears to play a crucial role in neonatal outcomes, including increased mean birth weight, reduced rates of intrauterine growth restriction (IUGR), and PE [67, 68].

Other antioxidant compounds such as selenium [69], allicin [70], coenzyme Q10 [71], N-acetylcysteine [72], $L$-arginine [73, 74], and vitamins $\mathrm{C}$ and $\mathrm{E}$ [75] have also been tested for the prevention and/or treatment of PE. However, the results are controversial, with evidence of null influence $[70,72,75]$ and beneficial action $[69,71,73,74]$ of antioxidants (Table 5). However, there is still insufficient evidence to recommend their use $[76,77]$. In addition, a meta-analysis conducted by Tenório et al. [78] aimed to determine whether oral antioxidant therapies, of various types and doses, were able to prevent or treat women with preeclampsia. In this study, antioxidant therapy had no effects in the prevention of PE but did show beneficial effects in intrauterine growth restriction, when used in the treatment of this condition.

Additionally, in vitro studies have been developed with other antioxidant compounds, such as resveratrol and melatonin, from cells involved in the pathogenesis of PE. The results were positive, suggesting their potential therapeutic use in the prevention and/or treatment of the disease [79-82]. The review of Kerleya et al. [83] discusses the use of ergothioneine as a possible mitochondrial target antioxidant, focusing on its physical properties, potential mechanisms of action, safety profile, and administration in relation to pregnancies complicated by PE.

Magnesium sulphate, widely used in clinical practice for the prevention of seizures in women with PE, has been studied in diseases involving the increase of oxidative stress by its potential action as an antioxidant, especially at the cellular and molecular levels, in addition to studies in animals and humans, with positive results. Thus, with further investigation, this compound may also be a preventive and/or therapeutic option for PE [84, 85].

In addition, other studies have evaluated the role of a mix of vitamins and minerals, including antioxidants, administered as enriched foods such as milk and bars, to prevent the onset of PE in women at high risk or with low concentration of these compounds. Wibowo et al. [86] and VadilloOrtega et al. [87] found positive results. That is, there was a decrease in the risk of PE in the supplemented women. However, it must be taken into account that such mix contained nutrients that do not play antioxidant roles, being difficult to judge the real effect of the antioxidant content.

Finally, despite the relationship mentioned between AGEs, inflammation, and oxidative stress in PE, there are few studies that used antioxidant and anti-inflammatory compounds in an associated way to prevent/minimize the adverse consequences to mother and fetus health. Stupakova et al. [88], in turn, aimed to evaluate the inhibition of platelet aggregation and the possibility of correction with resveratrol 
TABLE 6: Human research involving the oral supplementation of anti-inflammatory nutrients for the prevention and treatment of preeclampsia.

\begin{tabular}{|c|c|c|c|c|}
\hline Reference & Anti-inflammatory & Inclusion/exclusion criteria & Doses and administration period & Outcomes \\
\hline $\begin{array}{l}\text { D’Almeida et al. } \\
\text { (1992) [135] }\end{array}$ & $\begin{array}{c}\text { Group 1: control } \\
\text { Group 2: GLA, EPA, } \\
\text { DHA } \\
\text { Group 3: magnesium } \\
\text { oxide }\end{array}$ & $\begin{array}{l}\text { The patients were } \\
\text { primiparous and } \\
\text { multiparous and also had to } \\
\text { be in the first four months } \\
\text { of pregnancy to be eligible } \\
\text { to enroll in the program. }\end{array}$ & $\begin{array}{c}7 \mathrm{mg} \\
18 \mathrm{mg} \\
10 \mathrm{mg} \\
1000 \mathrm{mg}\end{array}$ & $\begin{array}{l}\downarrow \text { : incidence of edema in } \\
\text { group 2; group } 3 \text { had fewer } \\
\text { individuals who developed } \\
\text { hypertension during } \\
\text { pregnancy. Three cases of } \\
\text { eclampsia were reported in } \\
\text { the control group. }\end{array}$ \\
\hline $\begin{array}{l}\text { Herrera et al. } \\
(1998) \\
{[136]}\end{array}$ & $\begin{array}{c}\text { Intervention group: } \\
\text { linoleic acid, calcium } \\
\text { Control group: placebo } \\
\text { (lactose) }\end{array}$ & $\begin{array}{l}\text { Inclusion criteria: } 1^{\text {st }} \\
\text { pregnancy, gestational age } \\
\text { of } 28-32 \text { weeks, } \\
\text { biopsychosocial risk score } \\
\text { of } 3 \text { or more, positive roll- } \\
\text { over test, and high MAP. } \\
\text { Exclusion criteria: DBP of } \\
80 \text { mmHg or more at a } \\
\text { previous prenatal visit, drug } \\
\text { intake except for oral iron } \\
\text { supplements, and history of } \\
\text { SAH, CD, or RD. }\end{array}$ & $\begin{array}{c}450 \mathrm{mg} \\
600 \mathrm{mg} \\
600 \mathrm{mg} \\
28-32 \text { weeks until delivery }\end{array}$ & $\begin{array}{l}\downarrow: \text { incidence of PE in } \\
\text { high-risk women } v s \text {. } \\
\text { placebo group. }\end{array}$ \\
\hline $\begin{array}{l}\text { Bulstra- } \\
\text { Ramakers et al. } \\
\text { (1994) [76] }\end{array}$ & $\begin{array}{l}\text { Intervention group: EPA } \\
\text { and DHA } \\
\text { Group control: placebo } \\
\text { (coconut oil) }\end{array}$ & $\begin{array}{l}\text { Inclusion criteria: } \\
\text { birthweight below the 10th } \\
\text { centile corrected for } \\
\text { gestational age, parity, and } \\
\text { sex in association with PIH. } \\
\text { Birthweight below the 10th } \\
\text { centile in association with } \\
\text { RD. Birthweight below the } \\
\text { 10th centile and placental } \\
\text { abnormalities suggestive of } \\
\text { an impaired uteroplacental } \\
\text { circulation. } \\
\text { Exclusion criteria: women } \\
\text { with DM, systemic LE, or } \\
\text { other connective tissue } \\
\text { diseases; women with } \\
\text { whom it had already been } \\
\text { agreed previously that they } \\
\text { would be treated with low- } \\
\text { dose aspirin because of their } \\
\text { obstetric history. PIH was } \\
\text { defined as an increase in } \\
\text { diastolic blood pressure of } \\
\text { at least } 25 \text { mmHg in the } \\
\text { course of pregnancy, with a } \\
\text { final DBP. }\end{array}$ & $\begin{array}{c}3 \mathrm{~g} \\
12-14 \text { weeks until delivery }\end{array}$ & $\begin{array}{l}\text { No } \neq \text { between the } \\
\text { intervention group and the } \\
\text { placebo group. }\end{array}$ \\
\hline $\begin{array}{l}\text { Onwude et al. } \\
(1995)[77]\end{array}$ & $\begin{array}{c}\text { Intervention group: EPA } \\
\text { and DHA } \\
\text { Control group: placebo }\end{array}$ & $\begin{array}{c}\text { Inclusion criteria: } \\
\text { multigravida with (i) a } \\
\text { history of one or more small } \\
\text { babies, defined as } \\
\text { birthweight less than the } 3^{\text {rd }} \\
\text { centile; (ii) a history of } \\
\text { proteinuric or } \\
\text { nonproteinuric PIH, } \\
\text { defined as hypertension } \\
\text { (with or without } \\
\text { proteinuria) developing }\end{array}$ & $\begin{array}{c}1.62 \mathrm{~g} \\
1.08 \mathrm{~g} \\
16-20 \text { weeks until } 38 \text { weeks of } \\
\text { gestation }\end{array}$ & No $\neq$ between groups. \\
\hline
\end{tabular}


TABle 6: Continued.

\begin{tabular}{|c|c|c|c|c|}
\hline Reference & Anti-inflammatory & Inclusion/exclusion criteria & Doses and administration period & Outcomes \\
\hline & & $\begin{array}{l}\text { during pregnancy, labour, } \\
\text { and puerperium in a } \\
\text { previously normotensive } \\
\text { nonproteinuric woman; and } \\
\text { (iii) a history of } \\
\text { unexplained stillbirth. }\end{array}$ & & \\
\hline $\begin{array}{l}\text { Salving et al. } \\
(1996) \\
{[137]}\end{array}$ & $\begin{array}{l}\text { Intervention group: } \\
\text { fish oil } \\
\text { Group control: control } \\
\text { of the consumption of } \\
\text { olive oil }\end{array}$ & $\begin{array}{l}\text { Inclusion criteria: all } \\
\text { women attending the main } \\
\text { midwife clinic in the city of } \\
\text { Aarhus, Denmark, prior to } \\
30 \text { weeks of gestation. } \\
\text { Exclusion criteria: women } \\
\text { with a history of placental } \\
\text { abruption in an earlier } \\
\text { pregnancy or a serious } \\
\text { bleeding episode in the } \\
\text { present pregnancy. Women } \\
\text { using prostaglandin } \\
\text { inhibitors regularly and } \\
\text { allergy to fish and regular } \\
\text { intake of fish oil. }\end{array}$ & $\begin{array}{c}2.7 \mathrm{~g} \omega-3 \\
30 \text { weeks of gestation until delivery }\end{array}$ & $\begin{array}{c}\text { No } \neq \text { on systolic or diastolic } \\
\text { blood pressure. }\end{array}$ \\
\hline $\begin{array}{l}\text { Smuts et al. } \\
(2003) \\
{[138]}\end{array}$ & $\begin{array}{l}\text { Intervention group: eggs } \\
\text { enriched with DHA } \\
\text { Control group: } \\
\text { common egg }\end{array}$ & $\begin{array}{c}\text { Inclusion criteria: pregnant } \\
\text { women } 16-36 \text { years of age; } \\
24-28 \text { weeks of gestation, at } \\
\text { enrollment. Able and } \\
\text { willing to consume eggs. } \\
\text { Access to refrigeration. Plan } \\
\text { to deliver at Truman } \\
\text { Medical Center Singleton } \\
\text { gestation. } \\
\text { Exclusion criteria: }<16 \text { or } \\
>36 \text { years of age. Weight }> \\
240 \text { lb at baseline. Serious } \\
\text { illness such as cancer, LE, } \\
\text { and hepatitis, known to } \\
\text { have any untreated } \\
\text { infectious disease, DM, or } \\
\text { GDM at baseline. Elevated } \\
\text { blood pressure attributed to } \\
\text { any cause. }\end{array}$ & $\begin{array}{c}133 \mathrm{mg} / \text { unit } \\
33 \mathrm{mg} / \text { unit } \\
\text { 24-28 weeks of gestation until } \\
\text { delivery } \\
\text { (12 eggs/week of study) }\end{array}$ & $\begin{array}{c}\uparrow: \text { duration of gestation in } \\
\text { the intervention group }\end{array}$ \\
\hline $\begin{array}{l}\text { Olsen et al. } \\
(2000) \text { [139] }\end{array}$ & $\begin{array}{l}\text { Intervention group: } \\
\text { fish oil } \\
\text { Group control: olive oil }\end{array}$ & $\begin{array}{l}\text { Inclusion criteria: women } \\
\text { after } 16 \text { weeks of gestation } \\
\text { with an uncomplicated } \\
\text { pregnancy, who in an } \\
\text { earlier pregnancy had } \\
\text { experienced (a) preterm } \\
\text { delivery (before } 259 \text { days of } \\
\text { gestation), (b) IGR (<5th } \\
\text { centile), (c) PIH } \\
\text { (DBP > } 100 \text { mmHg), and } \\
\text { (d) women with current } \\
\text { twin pregnancies (trial D). } \\
\text { Exclusion criteria: DM in or } \\
\text { before pregnancy; } \\
\text { diagnosed severe fetal } \\
\text { malformation or hydrops in } \\
\text { current pregnancy; } \\
\text { suspicion in current } \\
\text { pregnancy, or occurrence in }\end{array}$ & $\begin{array}{l}2.7 \mathrm{~g} \omega-3 \text { (prophylactic) or } 6.1 \mathrm{~g} \omega \text { - } \\
3 \text { (therapeutic) } 20-33 \text { weeks until } \\
\text { delivery } \\
\end{array}$ & $\begin{array}{l}\downarrow: \text { risk of recurrence of } \\
\text { preterm labor in the } \\
\text { intervention group } v s . \\
\text { control. }\end{array}$ \\
\hline
\end{tabular}


TABLE 6: Continued.

\begin{tabular}{|c|c|c|c|c|}
\hline Reference & Anti-inflammatory & Inclusion/exclusion criteria & Doses and administration period & Outcomes \\
\hline & & $\begin{array}{l}\text { an earlier pregnancy, of } \\
\text { placental abruption; drug or } \\
\text { alcohol abuse; regular } \\
\text { intake of fish oil or of } \\
\text { nonsteroidal anti- } \\
\text { inflammatory agents or } \\
\text { other drugs with an effect } \\
\text { on thrombocyte function or } \\
\text { eicosanoid metabolism; and } \\
\text { allergy to fish products. }\end{array}$ & & \\
\hline
\end{tabular}

Legend: CD: cardiovascular disease; DBP: diastolic blood pressure; DHA: docosahexaenoic acid; DM: diabetes mellitus; EPA: eicosapentaenoic acid; GDM: gestational diabetes mellitus; GLA: gamma-linolenic acid; IUGR: intrauterine growth restriction; LE: lupus erythematosus; MAP: mean arterial pressure; PGE2: prostaglandin type E2; PIH: pregnancy-induced hypertension; RD: renal disease; SAH: systemic arterial hypertension; $\omega$-3: omega-3; $\uparrow$ : higher; $\downarrow$ : lower; $\neq$ : difference.

and nicorandil, in a rat model with PE induced by L-NAME. The findings were positive in relation to the drugs tested in order to aid in the homeostasis of the affected animals.

\section{PE vs Therapy with Anti- Inflammatory Compounds}

The oral use of anti-inflammatory nutrients in the prevention and treatment of PE has been addressed by the scientific community [66] (Table 6), with emphasis on omega-3. However, systematic reviews have concluded that omega-3 supplementation in PE pregnancy does not present beneficial effects either in the prevention or in the control of the pressure levels in the disease $[89,90]$. It is worth mentioning that $\mathrm{PE}$ has its origin in the initial period of pregnancy, even during the placentation process, and therefore, its prevention must be performed even before pregnancy has been established, which could justify the scarce results found in the literature $[8,15]$.

Currently, aspirin has been increasingly used to prevent PE. Although it consists of an inhibitor of platelet aggregation and a vasodilator, it also exerts an important anti-inflammatory action, acting in the reduction of prostaglandins and eicosanoids, thus reducing the inflammatory response [12, 91]. A meta-analysis performed by Askie et al. [92] evaluated the use of antiplatelet agents in the primary prevention of $\mathrm{PE}$ and observed an association of these with a moderate but consistent reduction in the relative risk of PE, as well as the occurrence of adverse effects.

Some studies are being conducted on aspirin and PE, many of which are reported on ClinicalTrials.gov. However, the results are still scarce and conflicting [93-95].

\section{Conclusions}

The supplementation with antioxidants, anti-inflammatory compounds, and nutrients has been considered in order to minimize the damage caused by oxidative stress and inflammation present in PE's pathophysiology. The results are still controversial. There is still no consensus on the best strategies for prevention and treatment of the disease, especially for the treatment of oxidative stress and inflammation, which are characteristics of the disease.

In view of the above, it is possible to establish an important relationship between oxidative stress and inflammatory process in the $\mathrm{PE}$ pathogenesis, considering that they are interconnected, acting on the various mechanisms involved in the disease. On the other hand, despite their relationship, the clinical and nutritional treatments described in the literature have not presented, so far, an effect, since they do not act on the cause of the disease, but in the sense of mitigating its consequences, not enough to prevent its progression. Thus, further research is urgently needed to elucidate the pathophysiology of this disease, in order to help health professionals, from the development of innovative therapeutic approaches to prevent and to treat $\mathrm{PE}$, and to contribute to reduce the serious health effects of the mother-fetus binomial.

\section{Conflicts of Interest}

The authors declare that they have no conflict of interest.

\section{Acknowledgments}

The authors wish to thank the Health Ministry of Brazil; the Brazilian National Council for Scientific and Technological Development (CNPq); the Foundation for Research Support of the State of Alagoas (FAPEAL), through the SUS Research Program (PPSUS); and the Coordination for the Improvement of Higher Education Personnel (CAPES), for grants and fellowships.

\section{References}

[1] World Health Organization, Recommendations of WHO for the Prevention and Treatment of Pre-Eclampsia and Eclampsia - Implications and Actions, WHO, Geneva, Switzerland, 2013.

[2] J. O. Lo, J. F. Mission, and A. B. Caughey, "Hypertensive disease of pregnancy and maternal mortality," Current Opinion in Obstetrics and Gynecology, vol. 25, no. 2, pp. 124-132, 2013. 
[3] M. V. B. Malachias, W. K. S. B. Souza, F. L. Plavnik et al., " $7^{\text {th }}$ Brazilian direction of hypertension," Brazilian Archives of Cardiology, vol. 107, pp. 1-83, 2016.

[4] The American College of Obstetricians and Gynecologists, "Hypertension in pregnancy. Report of the American College of Obstetricians and Gynecologists' task force on hypertension in pregnancy," Obstetrics \& Gynecology, vol. 122, no. 5, pp. 1122-1131, 2013.

[5] R. D. Williamson, C. McCarthy, F. P. McCarthy, and L. C. Kenny, "Oxidative stress in pre-eclampsia; have we been looking in the wrong place?," Pregnancy Hypertension: An International Journal of Women's Cardiovascular Health, vol. 8, pp. 1-5, 2017.

[6] T.'s.-T.'a. Hsieh, S. F. Chen, L. M. Lo, M. J. Li, Y. L. Yeh, and T. H. Hung, "The association between maternal oxidative stress at mid-gestation and subsequent pregnancy complications," Reproductive Sciences, vol. 19, no. 5, pp. 505-512, 2012.

[7] C. A. Turpin, S. A. Sakyi, W. K. B. A. Owiredu, R. K. D. Ephraim, and E. O. Anto, "Association between adverse pregnancy outcome and imbalance in angiogenic regulators and oxidative stress biomarkers in gestational hypertension and preeclampsia," BMC Pregnancy and Childbirth, vol. 15, no. 1, p. 189, 2015.

[8] T. Fournier, J. Guibourdenche, and D. Evain-Brion, "Review: hCGs: different sources of production, different glycoforms and functions," Placenta, vol. 36, pp. S60-S65, 2015.

[9] T. W. Sadler, Langman: Medical Embryology, Guanabara Koogan, Rio de Janeiro, Brazil, 9th edition, 2005.

[10] Institute of Medicine (US) and National Research Council (US) Committee to Reexamine IOM Pregnancy Weight Guidelines, Weight gain during pregnancy: reexamining the guidelines, National Academies Press, Washington, DC, USA, 2009.

[11] E. A. P. Steegers, P. von Dadelszen, J. J. Duvekot, and R. Pijnenborg, "Pre-eclampsia," The Lancet, vol. 376, no. 9741, pp. 631-644, 2010.

[12] B. W. J. Mol, C. T. Roberts, S. Thangaratinam, L. A. Magee, C. J. M. de Groot, and G. J. Hofmeyr, "Pre-eclampsia," The Lancet, vol. 387, no. 10022, pp. 999-1011, 2016.

[13] S. Sankaralingam, I. A. Arenas, M. M. Lalu, and S. T. Davidge, "Preeclampsia: current understanding of the molecular basis of vascular dysfunction," Expert Reviews in Molecular Medicine, vol. 8, no. 3, pp. 1-20, 2006.

[14] L. C. Sanchéz-Araguren, C. E. Prada, C. E. Riaño-Medina, and M. Lopez, "Endothelial dysfunction and preeclampsia: role of oxidative stress," Frontiers in Physiology, vol. 5, p. 372, 2014.

[15] R. S. Cotran, V. Kumar, and C. T. Robbins, Structural and Functional Pathology, Guanabara, Rio de Janeiro, Brazil, 6th edition, 2000.

[16] O. C. Silva Jr., S. Centurion, E. G. Pacheco, J. L. Brisotti, A. F. Oliveira, and K. D. Sasso, "Basic aspects of ischemia and reperfusion injury and ischemic preconditioning," Acta Cirurgica Brasileira, vol. 17, pp. 96-100, 2002.

[17] D. M. S. Tardini and W. B. Yoshida, "Brain lesions due to ischemia and reperfusion in carotid endarterectomy surgery," Jornal Vascular Brasileiro, vol. 2, pp. 119-128, 2003.

[18] A. Yildirim, K. Altinkaynak, H. Aksoy, Y. N. Sahin, and F. Akcay, "Plasma xanthine oxidase, superoxide dismutase and glutathione peroxidase activities and uric acid levels in severe and mild pre-eclampsia," Cell Biochemistry and Function, vol. 22, no. 4, pp. 213-217, 2004.

[19] A. Many, C. A. Hubel, S. J. Fisher, J. M. Roberts, and Y. Zhou, "Invasive cytotrophoblasts manifest evidence of oxidative stress in preeclampsia," The American Journal of Pathology, vol. 156, no. 1, pp. 321-331, 2000.

[20] B. C. White, J. M. Sullivan, D. J. Degracia et al., "Brain ischemia and reperfusion: molecular mechanisms of neuronal injury," Journal of the Neurological Sciences, vol. 179, no. 1-2, pp. 1-33, 2000.

[21] A. Kunz, U. Dirnagl, and P. Mergenthaler, "Acute pathophysiological processes after ischaemic and traumatic brain injury," Best Practice \& Research Clinical Anaesthesiology, vol. 24, no. 4, pp. 495-509, 2010.

[22] E. B. P. Campos and W. B. Yoshida, "The role of free radicals in the pathophysiology of ischemia and reperfusion in cutaneous flaps: experimental models and treatment strategies," Jornal Vascular Brasileiro, vol. 3, pp. 357-366, 2004.

[23] M. Zhao, Y. Yin, J. Wei, M. Wu, C. Yang, and Q. Chen, “Trophoblastic debris extruded from hydatidiform molar placentae activates endothelial cells: possible relevance to the pathogenesis of preeclampsia," Placenta, vol. 45, pp. 42-49, 2016.

[24] L. G. Artico, J. M. Madi, A. E. Godoy, C. P. Coelho, R. L. Rombaldi, and G. R. Artico, "Histopathological changes in human placentas related to hypertensive disorders," Revista Brasileira de Ginecologia e Obstetrícia, vol. 31, no. 1, pp. 10-16, 2009.

[25] S. Shevade, V. Arole, V. Bharambe, and V. Paranjape, "Placental morphology and fetal outcome in pre-eclampsia and normotense pregnancies," IOSR Journal of Dental and Medical Sciences, vol. 14, no. 4, pp. 11-15, 2015.

[26] K. D. Sankar, P. S. Bhanu, K. Ramalingam, S. Kiran, and B. A. Ramakrishna, "Histomorphological and morphometrical changes of placental terminal villi of normotensive and preeclamptic mothers," Anatomy \& Cell Biology, vol. 46, no. 4, pp. 285-290, 2013.

[27] M. S. Rogers, C. C. Wang, W. H. Tam, C. Y. Li, K. O. Chu, and C. Y. Chu, "Oxidative stress in midpregnancy as a predictor of gestational hypertension and pre-eclampsia," BJOG: An International Journal of Obstetrics \& Gynaecology, vol. 113, no. 9, pp. 1053-1059, 2006.

[28] Ö. B. Yiyenoğlu, M. G. Uğur, H. Ç. Özcan et al., “Assessment of oxidative stress markers in recurrent pregnancy loss: a prospective study," Archives of Gynecology and Obstetrics, vol. 289, no. 6, article 3113, pp. 1337-1340, 2014.

[29] C. W. G. Redman, "Pre-eclampsia and the placenta," Placenta, vol. 12, no. 4, pp. 301-308, 1991.

[30] L. Poston, N. Igosheva, H. D. Mistry et al., "Role of oxidative stress and antioxidant supplementation in pregnancy disorders," The American Journal of Clinical Nutrition, vol. 94, Supplement 6, pp. 1980S-1985S, 2011.

[31] C. L. Quinlan, R. L. S. Goncalves, M. Hey-Mogensen, N. Yadava, V. I. Bunik, and M. D. Brand, "The 2-Oxoacid dehydrogenase complexes in mitochondria can produce superoxide/hydrogen peroxide at much higher rates than complex I," Journal of Biological Chemistry, vol. 289, no. 12, pp. 8312-8325, 2014. 
[32] V. Chamy, J. Lepe, A. Catalan, D. Retamal, J. A. Escobar, and E. M. Madrid, "Oxidative stress is closely related to clinical severity of pre-eclampsia," Biological Research, vol. 39, no. 2, pp. 229-236, 2006.

[33] M. T. M. Raijmakers, R. Dechend, and L. Poston, "Oxidative stress and Preeclampsia," Hypertension, vol. 44, no. 4, pp. 374-380, 2004.

[34] R. Aouache, L. Biquard, D. Vaiman, and F. Miralles, "Oxidative stress in preeclampsia and placental diseases," International Journal of Molecular Sciences, vol. 19, no. 5, p. 1496, 2018.

[35] S. Sankaralingam, Y. Xu, T. Sawamura, and S. T. Davidge, "Increased lectin-like oxidized low-density lipoprotein receptor-1 expression in the maternal vasculature of women with preeclampsia: role for peroxynitrite," Hypertension, vol. 53, no. 2, pp. 270-277, 2009.

[36] A. C. Harmon, D. C. Cornelius, L. M. Amaral et al., "The role of inflammation in the pathology of preeclampsia," Clinical Science, vol. 130, no. 6, pp. 409-419, 2016.

[37] D. I. Chiarello, C. Abad, D. Rojas et al., "Oxidative stress: normal pregnancy versus preeclampsia," Biochimica et Biophysica Acta (BBA) - Molecular Basis of Disease, 2018.

[38] G. Chen, R. Wilson, S. H. Wang, H. Z. Zheng, J. J. Walker, and J. H. Mckillop, "Tumour necrosis factor-alpha (TNF- $\alpha$ ) gene polymorphism and expression in pre-eclampsia," Clinical and Experimental Immunology, vol. 104, no. 1, pp. 154-159, 1996.

[39] I. Striz, E. Brabcova, L. Kolesar et al., "Epithelial cells modulate genes associated with NF kappa B activation in cocultured human macrophages," Immunobiology, vol. 216, no. 10, pp. 1110-1116, 2011.

[40] P. Dhillion, K. Wallace, F. Herse et al., "IL-17-mediated oxidative stress is an important stimulator of AT1-AA and hypertension during pregnancy," American Journal of Physiology-Regulatory, Integrative and Comparative Physiology, vol. 303, no. 4, pp. R353-R358, 2012.

[41] L. I. Filippin, R. Vercelino, N. A. P. Marroni, and R. M. Xavier, "Influence of redox processes on the inflammatory response of rheumatoid arthritis," Revista Brasileira de Reumatologia, vol. 48, p. 1724, 2008.

[42] D. S. Charnock-Jones, "Placental hypoxia, endoplasmic reticulum stress and maternal endothelial sensitisation by sFLT1 in pre-eclampsia," Journal of Reproductive Immunology, vol. 114, pp. 81-85, 2016.

[43] J. Qian and D. Fulton, "Post-translational regulation of endothelial nitric oxide synthase in vascular endothelium," Frontiers in Physiology, vol. 4, p. 347, 2013.

[44] T. Groten, T. Lehmann, J. Fitzgerald et al., "Reduction of preeclampsia related complications with with the NO-donor penterythriltetranitrat (PETN) in risk pregnancies - a prospective randomized double-blind placebo pilot study," Journal of Reproductive Immunology, vol. 94, no. 1, p. 120, 2012.

[45] S. E. Maynard, J. Y. Min, J. Merchan et al., "Excess placental soluble fms-like tyrosine kinase 1 (sFlt1) may contribute to endothelial dysfunction, hypertension, and proteinuria in preeclampsia," Journal of Clinical Investigation, vol. 111, no. 5, pp. 649-658, 2003.

[46] J. P. Granger, B. T. Alexander, M. T. Llinas, W. A. Bennett, and R. A. Khalil, "Pathophysiology of hypertension during preeclampsia linking placental ischemia with endothelial dysfunction," Hypertension, vol. 38, no. 3, pp. 718-722, 2001.
[47] F. Herse and B. LaMarca, "Angiotensin II type 1 receptor autoantibody (AT1-AA)-mediated pregnancy hypertension," American Journal of Reproductive Immunology, vol. 69, no. 4, pp. 413-418, 2013.

[48] J. Lei, Y. Li, S. Zhang, Y. Wu, P. Wang, and H. Liu, “The prognostic role of angiotensin II type 1 receptor autoantibody in non-gravid hypertension and pre-eclampsia: a meta-analysis and our studies," Medicine, vol. 95, no. 17, article e3494, 2016.

[49] A. Szpera-Gozdziewicz, T. Gozdziewicz, P. Wirstlein, E. Wender-Ozegowska, and G. H. Breborowicz, "The agonistic autoantibodies to the angiotensin II type 1 receptor in pregnancies complicated by hypertensive disorders," The Journal of Maternal-Fetal \& Neonatal Medicine, vol. 32, no. 7, pp. 1219-1223, 2019.

[50] M. W. Cunningham Jr., J. Castillo, T. Ibrahim et al., “AT1AA (angiotensin II type 1 receptor agonistic autoantibody) blockade prevents preeclamptic symptoms in placental ischemic rats," Hypertension, vol. 71, no. 5, pp. 886-893, 2018.

[51] B. Lamarca, "Endothelial dysfunction; an important mediator in the pathophysiology of hypertension during preeclampsia," Minerva Ginecologica, vol. 64, no. 4, pp. 309-320, 2012.

[52] I. L. Sargent, S. J. Germain, G. P. Sacks, S. Kumar, and C. W. G. Redman, "Trophoblast deportation and the maternal inflammatory response in pre-eclampsia," Journal of Reproductive Immunology, vol. 59, no. 2, pp. 153-160, 2003.

[53] L. Guedes-Martins, L. Matos, A. Soares, E. Silva, and H. Almeida, "AGEs, contributors to placental bed vascular changes leading to preeclampsia," Free Radical Research, vol. 47, Supplement 1, pp. 70-80, 2013.

[54] J. F. Bilodeau, "Review: maternal and placental antioxidant response to preeclampsia - impact on vasoactive eicosanoids," Placenta, vol. 35, pp. S32-S38, 2014.

[55] R. Negi, D. Pande, K. Karki, A. Kumar, R. S. Khanna, and H. D. Khanna, "Association of oxidative DNA damage, protein oxidation and antioxidant function with oxidative stress induced cellular injury in pre-eclamptic/eclamptic mothers during fetal circulation," Chemico-Biological Interactions, vol. 208, pp. 77-83, 2014.

[56] S. Gupta, A. Agarwal, and R. K. Sharma, "The role of placental oxidative stress and lipid peroxidation in preeclampsia," Obstetrical \& Gynecological Survey, vol. 60, no. 12, pp. 807816, 2005.

[57] J. S. M. Cuffe, Z. C. Xu, and A. V. Perkins, "Biomarkers of oxidative stress in pregnancy complications," Biomarkers in Medicine, vol. 11, no. 3, pp. 295-306, 2017.

[58] M. Cackovic, C. S. Buhimschi, G. Zhao et al., "Fractional excretion of tumor necrosis factor- $\alpha$ in women with severe preeclampsia," Obstetrics \& Gynecology, vol. 112, no. 1, pp. 93-100, 2008.

[59] V. C. Sandrim, A. C. T. Palei, I. F. Metzger, V. A. Gomes, R. C. Cavalli, and J. E. Tanus-Santos, "Nitric oxide formation is inversely related to serum levels of antiangiogenic factors soluble fms-like tyrosine kinase-1 and soluble endogline in preeclampsia," Hypertension, vol. 52, no. 2, pp. 402-407, 2008.

[60] A. M. Borzychowski, I. L. Sargent, and C. W. G. Redman, "Inflammation and pre-eclampsia," Seminars in Fetal and Neonatal Medicine, vol. 11, no. 5, pp. 309-316, 2006.

[61] P. Gathiram and J. Moodley, "Pre-eclampsia: its pathogenesis and pathophysiolgy," Cardiovascular Journal of Africa, vol. 27, no. 2, pp. 71-78, 2016. 
[62] B. LaMarca, J. Speed, L. F. Ray et al., "Hypertension in response to IL-6 during pregnancy: role of AT1-receptor activation," International Journal of Interferon, Cytokine and Mediator Research, vol. 3, pp. 65-70, 2011.

[63] Z. Lai, S. Kalkunte, and S. Sharma, "A critical role of interleukin-10 in modulating hypoxia-induced preeclampsialike disease in mice," Hypertension, vol. 57, no. 3, pp. 505-514, 2011.

[64] B. B. D. LaMarca, K. Cockrell, E. Sullivan, W. Bennett, and J. P. Granger, "Role of endothelin in mediating tumor necrosis factor-induced hypertension in pregnant rats," Hypertension, vol. 46, no. 1, pp. 82-86, 2005.

[65] D. M. C. e Silva, D. do Nascimento Marreiro, J. M. M. Neto et al., "Oxidative stress and immunological alteration in women with preeclampsia," Hypertension in Pregnancy, vol. 32, no. 3, pp. 304-311, 2013.

[66] D. Aprialdi, H. Susiarno, S. SetyoriniIrianti et al., "The effects of combined omega-3 and vitamin E supplementation on preeclampsia cases in Hasan Sadikin Hospital Bandung," International Journal of PharmTech Research, vol. 9, pp. 320-325, 2016.

[67] S. Banerjee, S. Jeyaseelan, and R. Guleria, "Trial of lycopene to prevent pre-eclampsia in healthy primigravidas: Results show some adverse effects," Journal of Obstetrics and Gynaecology Research, vol. 35, no. 3, pp. 477-482, 2009.

[68] J. B. Sharma, A. Kumar, A. Kumar et al., "Effect of lycopene on pre-eclampsia and intra-uterine growth retardation in primigravidas," International Journal of Gynaecology and Obstetrics, vol. 81, no. 3, pp. 257-262, 2003.

[69] F. Tara, G. Maamouri, M. P. Rayman et al., "Selenium supplementation and the incidence of preeclampsia in pregnant Iranian women: a randomized, double-blind, placebo-controlled pilot trial," Taiwanese Journal of Obstetrics and Gynecology, vol. 49, no. 2, pp. 181-187, 2010.

[70] R. Aalami-Harandi, M. Karamali, and Z. Asemi, "The favorable effects of garlic intake on metabolic profiles, hs-CRP, biomarkers of oxidative stress and pregnancy outcomes in pregnant women at risk for pre-eclampsia: randomized, double-blind, placebo-controlled trial," The Journal of MaternalFetal \& Neonatal Medicine, vol. 28, no. 17, pp. 2020-2027, 2015.

[71] E. Teran, I. Hernandez, B. Nieto, R. Tavara, J. E. Ocampo, and A. Calle, "Coenzyme Q10 supplementation during pregnancy reduces the risk of pre-eclampsia," International Journal of Gynecology \& Obstetrics, vol. 105, no. 1, pp. 43-45, 2009.

[72] S. M. Motawei, S. M. Attalla, H. E. Gouda, M. A. Harouny, and A. M. Elmansoury, "The effects of $\mathrm{N}$-acetyl cysteine on oxidative stress among patients with pre-eclampsia," International Journal of Gynecology \& Obstetrics, vol. 135, no. 2, pp. 226-227, 2016.

[73] E. E. C. Pulido, L. G. Benavides, J. G. P. Barón et al., "Efficacy of L-arginine for preventing preeclampsia in high-risk pregnancies: a double-blind, randomized, clinical trial," Hypertension in Pregnancy, vol. 35, no. 2, pp. 217-225, 2016.

[74] J. E. Valdivia-Silva, K. López-Molina, and R. Macedo, “Effect of early L-arginine therapy on intrauterine growth restriction in preeclampsia. A randomized controlled trial in LatinAmerican women," Progresos de Obstetricia y Ginecología, vol. 52, no. 2, pp. 89-98, 2009.
[75] J. A. Spinnato II, S. Freire, J. L. Pinto e Silva et al., "Antioxidant therapy to prevent preeclampsia: a randomized controlled trial," Obstetrics \& Gynecology, vol. 110, no. 6, pp. 1311-1318, 2007.

[76] M. T. E. W. Bulstra-Ramakers, H. J. Huisjes, and G. H. A. Visser, "The effects of $3 g$ eicosapentaenoic acid daily on recurrence of intrauterine growth retardation and pregnancy induced hypertension," BJOG: An International Journal of Obstetrics and Gynaecology, vol. 102, no. 2, pp. 123-126, 1995.

[77] J. L. Onwude, R. J. Lilford, H. Hjartardottir, A. Staines, and D. Tuffnell, "A randomised double blind placebo controlled trial of fish oil in high risk pregnancy," BJOG: An International Journal of Obstetrics and Gynaecology, vol. 102, no. 2, pp. 95-100, 1995.

[78] M. B. Tenório, R. C. Ferreira, F. A. Moura, N. B. Bueno, M. O. F. Goulart, and A. C. M. Oliveira, "Oral antioxidant therapy for prevention and treatment of preeclampsia: Metaanalysis of randomized controlled trials," Nutrition, Metabolism and Cardiovascular Diseases, vol. 28, no. 9, pp. 865-876, 2018.

[79] N. J. Hannan, N. K. Binder, S. Beard, T. V. Nguyen, T.'. J. Kaitu'u-Lino, and S. Tong, "Melatonin enhances antioxidant molecules in the placenta, reduces secretion of soluble fms-like tyrosine kinase 1 (sFLT) from primary trophoblast but does not rescue endothelial dysfunction: an evaluation of its potential to treat preeclampsia," PLoS One, vol. 13, no. 4, article e0187082, 2018.

[80] N. J. Hannan, F. C. Brownfoot, P. Cannon et al., "Resveratrol inhibits release of soluble fms-like tyrosine kinase (sFlt-1) and soluble endoglin and improves vascular dysfunction implications as a preeclampsia treatment," Scientific Reports, vol. 7, no. 1, p. 1819, 2017.

[81] M. Zhao, Y. Li, L. Xu et al., "Melatonin prevents preeclamptic sera and antiphospholipid antibodies inducing the production of reactive nitrogen species and extrusion of toxic trophoblastic debris from first trimester placentae," Placenta, vol. 58, pp. 17-24, 2017.

[82] S. R. Hobson, E. M. Wallace, J. C. Kingdom, and R. J. Hodges, "A randomized double-blinded placebo-controlled intervention trial of melatonin for the prevention of preeclampsia in moderate- and high-risk women: the MELPOP trial," in Preeclampsia, vol. 1710 of Methods in Molecular Biology, pp. 347-352, Humana Press, New York, NY, USA, 2018.

[83] R. N. Kerley, C. McCarthy, D. B. Kell, and L. C. Kenny, "The potential therapeutic effects of ergothioneine in pre-eclampsia," Free Radical Biology and Medicine, vol. 117, pp. 145157, 2018.

[84] C. Abad, F. R. Vargas, T. Zoltan et al., "Magnesium sulfate affords protection against oxidative damage during severe preeclampsia," Placenta, vol. 36, no. 2, pp. 179-185, 2015.

[85] A. A. Zheltova, M. V. Kharitonova, I. N. Iezhitsa, and A. A. Spasov, "Magnesium deficiency and oxidative stress: an update," BioMedicine, vol. 6, no. 4, article 20, 2016.

[86] N. Wibowo, Y. Purwosunu, A. Sekizawa, A. Farina, L. Idriansyah, and I. Fitriana, "Antioxidant supplementation in pregnant women with low antioxidant status," Journal of Obstetrics and Gynaecology Research, vol. 38, no. 9, pp. 1152-1161, 2012.

[87] F. Vadillo-Ortega, O. Perichart-Perera, S. Espino et al., "Effect of supplementation during pregnancy with L-arginine and antioxidant vitamins in medical food on pre-eclampsia in 
high risk population: randomised controlled trial," $B M J$, vol. 342, no. may19 1, p. d2901, 2011.

[88] E. G. Stupakova, G. A. Lazareva, V. V. Gureev, I. N. Dolzhikova, L. A. Zhilinkova, and A. V. Gureeva, "L-NAMEinduced preeclampsia: correction of functional disorders of the hemostasis system with resveratrol and nicorandil," Research Results in Pharmacology, vol. 5, no. 2, pp. 1-12, 2019.

[89] B. Imhoff-Kunsch, V. Briggs, T. Goldenberg, and U. Ramakrishnan, "Effect of n-3 long-chain polyunsaturated fatty acid intake during pregnancy on maternal, infant, and child health outcomes: a systematic review," Paediatric and Perinatal Epidemiology, vol. 26, pp. 91-107, 2012.

[90] G. Saccone, I. Saccone, and V. Berghella, "Omega-3 longchain polyunsaturated fatty acids and fish oil supplementation during pregnancy: which evidence?," The Journal of Maternal-Fetal \& Neonatal Medicine, vol. 29, pp. 1-9, 2016.

[91] J. M. Roberts and J. M. Catov, "Aspirin for pre-eclampsia: compelling data on benefit and risk," The Lancet, vol. 369, no. 9575, pp. 1765-1766, 2007.

[92] L. M. Askie, L. Duley, D. J. Henderson-Smart, and L. A. Stewart, "Antiplatelet agents for prevention of pre-eclampsia: a meta-analysis of individual patient data," Lancet, vol. 369, no. 9575, pp. 1791-1798, 2007.

[93] A. O. Odibo, K. R. Goetzinger, L. Odibo, and M. G. Tuuli, "Early prediction and aspirin for prevention of preeclampsia (EPAPP) study: a randomized controlled trial," Ultrasound in Obstetrics \& Gynecology, vol. 46, no. 4, pp. 414-418, 2015.

[94] B. Haddad, N. Winer, Y. Chitrit et al., "Enoxaparin and aspirin compared with aspirin alone to prevent placentamediated pregnancy complications: a randomized controlled trial," Obstetrics \& Gynecology, vol. 128, no. 5, pp. 1053-1063, 2016.

[95] D. E. Ayala, R. Ucieda, and R. C. Hermida, "Chronotherapy with low-dose aspirin for prevention of complications in pregnancy," Chronobiology International, vol. 30 , no. 1-2, pp. 260-279, 2013.

[96] M. P. Rayman, E. Searle, L. Kelly et al., "Effect of selenium on markers of risk of pre-eclampsia in UK pregnant women: a randomised, controlled pilot trial," British Journal of Nutrition, vol. 112, no. 1, pp. 99-111, 2014.

[97] P. Takacs, S. W. Kauma, M. M. Sholley, S. W. Walsh, M. J. Dinsmoor, and K. Green, "Increased circulating lipid peroxides in severe preeclampsia activate NF- $\kappa \mathrm{B}$ and upregulate ICAM-1 in vascular endothelial cells," The FASEB Journal, vol. 15, no. 2, pp. 279-281, 2001.

[98] L. A. Rabelo, F. O. Ferreira, V. Nunes-Souza, L. J. S. Fonseca, and M. O. F. Goulart, "Arginase as a critical prooxidant mediator in the binomial endothelial dysfunction-atherosclerosis," Oxidative Medicine and Cellular Longevity, vol. 2015, Article ID 924860, 12 pages, 2015.

[99] D. Coman, J. Yaplito-Lee, and A. Boneh, "New indications and controversies in arginine therapy," Clinical Nutrition, vol. 27, no. 4, pp. 489-496, 2008.

[100] S. M. Morris Jr., "Enzymes of arginine metabolism," The Journal of Nutrition, vol. 134, no. 10, pp. 2743S-2747S, 2004.

[101] C. M. B. Oliveira, R. K. Sakata, A. M. Issy, L. R. Gerola, and R. Salomão, "Cytokines and pain," Revista Brasileira de Anestesiologia, vol. 61, pp. 255-265, 2011.
[102] J. H. Curfs, J. F. Meis, and J. A. Hoogkamp-Korstanje, “A primer on cytokines: sources, receptors, effects, and inducers," Clinical Microbiology Reviews, vol. 10, no. 4, pp. 742-780, 1997.

[103] A. R. de Vivar Chavez, W. Buchser, P. H. Basse et al., "Pharmacologic Administration of Interleukin-2," Annals of the New York Academy of Sciences, vol. 1182, no. 1, pp. 14-27, 2009.

[104] D. C. T. Palomino and L. C. Marti, "Chemokines and immunity," Einstein, vol. 13, no. 3, pp. 469-473, 2015.

[105] A. C. P. Volp, R. C. G. Alfenas, N. M. B. Costa, V. P. R. Minim, P. C. Stringueta, and J. Bressan, "Capacidade dos biomarcadores inflamatórios em predizer a síndrome metabólica: inflammation biomarkers capacity in predicting the metabolic syndrome," Arquivos Brasileiros de Endocrinologia \& Metabologia, vol. 52, no. 3, pp. 537-549, 2008.

[106] M. L. Blanco and N. A. Condino, "The nuclear factor kappa B: a new perspective for the study of anti-inflammatory drugs," Journal of Medical Sciences, vol. 12, no. 4, pp. 341349, 2003.

[107] S. M. L. Vasconcelos, M. O. F. Goulart, J. B. F. Moura, V. Manfredini, M. S. Benfato, and L. T. Kubota, "Espécies reativas de oxigênio e de nitrogênio, antioxidantes e marcadores de dano oxidativo em sangue humano: principais métodos analíticos para sua determinação," Química Nova, vol. 30, no. 5, pp. 1323-1338, 2007.

[108] B. Halliwell and J. M. C. Gutteridge, Free Radical in Biology and Medicine, Oxford University Press, Oxford, UK, 5th edition, 2015.

[109] D. R. Petersen and J. A. Doorn, "Reactions of 4-hydroxynonenal with proteins and cellular targets," Free Radical Biology \& Medicine, vol. 37, no. 7, pp. 937-945, 2004.

[110] A. L. B. S. Barreiros, J. M. David, and J. P. David, "Estresse oxidativo: relação entre geração de espécies reativas e defesa do organismo," Química Nova, vol. 29, no. 1, pp. 113-123, 2006.

[111] M. E. Shils, J. Á. Olson, M. Shike, and A. C. Ross, Treaty on Modern Nutrition in Health and Sickness, Manole, São Paulo, Brazil, 9th edition, 2002.

[112] A. Theriault, J. T. Chao, Q. Wang, A. Gapor, and K. Adeli, "Tocotrienol: a review of its therapeutic potential," Clinical Biochemistry, vol. 32, no. 5, pp. 309-319, 1999.

[113] Y. Atamer, Y. Koçyigit, B. Yokus, A. Atamer, and A. C. Erden, "Lipid peroxidation, antioxidant defense, status of trace metals and leptin levels in preeclampsia," European Journal of Obstetrics \& Gynecology and Reproductive Biology, vol. 119, no. 1, pp. 60-66, 2005.

[114] S. Aydin, A. Benian, R. Madazli, S. Uludag, H. Uzun, and S. Kaya, "Plasma malondialdehyde, superoxide dismutase, sE-selectin, fibronectin, endothelin-1 and nitric oxide levels in women with preeclampsia," European Journal of Obstetrics \& Gynecology and Reproductive Biology, vol. 113, no. 1, pp. 21-25, 2004.

[115] Y. Yoneyama, R. Sawa, S. Suzuki et al., "Relationship between plasma malondialdehyde levels and adenosine deaminase activities in preeclampsia," Clinica Chimica Acta, vol. 322, no. 1-2, pp. 169-173, 2002.

[116] H. Orhan, L. Onderoglu, A. Yucel, and G. Sahin, "Circulating biomarkers of oxidative stress in complicated pregnancies," Archives of Gynecology and Obstetrics, vol. 267, no. 4, pp. 189-195, 2003. 
[117] C. A. Hubel, M. K. McLaughlin, R. W. Evans, B. A. Hauth, C. J. Sims, and J. M. Roberts, "Fasting serum triglycerides, free fatty acids, and malondialdehyde are increased in preeclampsia, are positively correlated, and decrease within 48 hours post partum," American Journal of Obstetrics and Gynecology, vol. 174, no. 3, pp. 975-982, 1996.

[118] Z. Serdar, E. Gür, M. Colakoethullarý, O. Develioethlu, and E. Sarandöl, "Lipid and protein oxidation and antioxidant function in women with mild and severe preeclampsia," Archives of Gynecology and Obstetrics, vol. 268, no. 1, pp. 19-25, 2003.

[119] I. A. Siddiqui, A. Jaleel, H. M. F. al'Kadri, S. Akram, and W. Tamimi, "Biomarkers of oxidative stress in women with pre-eclampsia," Biomarkers in Medicine, vol. 7, no. 2, pp. 229-234, 2013.

[120] A. S. Sahay, D. P. Sundrani, G. N. Wagh, S. S. Mehendale, and S. R. Joshi, "Regional differences in the placental levels of oxidative stress markers in pre-eclampsia," International Journal of Gynecology \& Obstetrics, vol. 129, no. 3, pp. 213-218, 2015.

[121] H. U. Yuvaci, N. Akdemir, M. S. Bostanci et al., "Evaluation of the level of thiol-disulphide homeostasis in patients with mild and severe preeclampsia," Pregnancy Hypertension: An International Journal of Women's Cardiovascular Health, vol. 6, no. 4, pp. 394-399, 2016.

[122] L. de Lucca, F. Rodrigues, L. B. Jantsch et al., "Delta-aminolevulinate dehydratase activity and oxidative stress markers in preeclampsia," Biomedicine \& Pharmacotherapy, vol. 84, pp. 224-229, 2016.

[123] S. Sahin, O. B. Ozakpinar, M. Eroglu et al., "The impact of platelet functions and inflammatory status on the severity of preeclampsia," The Journal of Maternal-Fetal \& Neonatal Medicine, vol. 28, no. 6, pp. 643-648, 2015.

[124] A. Molvarec, I. Czegle, J. Szijártó, and J. Rigó Jr., "Increased circulating interleukin-17 levels in preeclampsia," Journal of Reproductive Immunology, vol. 112, pp. 53-57, 2015.

[125] L. Sun, D. Mao, Y. Cai et al., "Association between higher expression of interleukin-8 (IL-8) and haplotype $-353 \mathrm{~A} /-251 \mathrm{~A} /+678 \mathrm{~T}$ of $I L-8$ gene with preeclampsia: A case-control study," Medicine, vol. 95, no. 52, article e5537, 2016.

[126] V. R. Ribeiro, M. Romao-Veiga, G. G. Romagnoli et al., "Association between cytokine profile and transcription factors produced by T-cell subsets in early- and late-onset preeclampsia," Immunology, vol. 152, no. 1, pp. 163-173, 2017.

[127] R. Aggarwal, A. K. Jain, P. Mittal, M. Kohli, P. Jawanjal, and G. Rath, "Association of pro- and anti-inflammatory cytokines in preeclampsia," Journal of Clinical Laboratory Analysis, vol. 33, no. 4, article e22834, 2019.

[128] A. B. Peixoto, E. Araujo Júnior, J. U. Ribeiro et al., "Evaluation of inflammatory mediators in the deciduas of pregnant women with pre-eclampsia/eclampsia," The Journal of Maternal-Fetal \& Neonatal Medicine, vol. 29, no. 1, pp. 7579, 2015.

[129] F. Kalantar, S. Rajaei, A. B. Heidari et al., "Serum levels of tumor necrosis factor- $\alpha$, interleukin-15 and interleukin-10 in patients with pre-eclampsia in comparison with normotensive pregnant women," Iranian Journal of Nursing and Midwifery, vol. 18, no. 6, pp. 463-466, 2013.

[130] M. Kalinderis, A. Papanikolaou, K. Kalinderi et al., "Elevated serum levels of interleukin-6, interleukin- $1 \beta$ and human chorionic gonadotropin in pre-eclampsia," American Journal of Reproductive Immunology, vol. 66, no. 6, pp. 468-475, 2011.
[131] R. H. el-Kabarity and A. H. Naquib, "Serum levels of IL-18, IL-12 and TH-1/TH-2 ratio in patients with pre-eclampsia," The Egyptian Journal of Immunology, vol. 18, no. 1, pp. 1-8, 2011.

[132] D. Sharma, A. Singh, S. S. Trivedi, and J. Bhattacharjee, "Role of endothelin and inflammatory cytokines in pre-eclampsia a pilot North Indian study," American Journal of Reproductive Immunology, vol. 65, no. 4, pp. 428-432, 2011.

[133] H. Xu, R. Perez-Cuevas, X. Xiong et al., "An international trial of antioxidants in the prevention of preeclampsia (INTAPP)," American Journal of Obstetrics and Gynecology, vol. 202, no. 3, pp. 239.e1-239.e10, 2010.

[134] J. M. Roberts, L. Myatt, C. Y. Spong et al., "Vitamins C and E to prevent complications of pregnancy-associated hypertension," The New England Journal of Medicine, vol. 362, no. 14, pp. 1282-1291, 2010.

[135] A. D'Almeida, J. P. Carter, A. Anatol, and C. Prost, "Effects of a combination of evening primrose oil (gamma linolenic acid) and fish oil (eicosapentaenoic + Docahexaenoic acid) versus magnesium, and versus placebo in preventing PreEclampsia," Women \& Health, vol. 19, no. 2-3, pp. 117-131, 1992.

[136] J. A. Herrera, M. Arevalo-Herrera, and S. Herrera, "Prevention of preeclampsia by linoleic acid and calcium supplementation: a randomized controlled trial," Obstetrics \& Gynecology, vol. 91, no. 4, pp. 585-590, 1998.

[137] J. D. Salvig, S. F. Olsen, and N. J. Secher, "Effects of fish oil supplementation in late pregnancy on blood pressure: a randomised controlled trial," BJOG: An International Journal of Obstetrics and Gynaecology, vol. 103, no. 6, pp. 529-533, 1996.

[138] C. M. Smuts, M. Huang, D. Mundy, T. Plasse, S. Major, and S. E. Carlson, "A randomized trial of docosahexaenoic acid supplementation during the third trimester of pregnancy," Obstetrics \& Gynecology, vol. 101, no. 3, pp. 469-479, 2003.

[139] S. F. Olsen, N. J. Secher, A. Tabor, T. Weber, J. J. Walker, and C. Gluud, "Randomised clinical trials of fish oil supplementation in high risk pregnancies," BJOG: An International Journal of Obstetrics and Gynaecology, vol. 107, no. 3, pp. 382-395, 2000. 


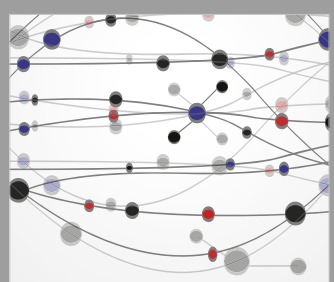

The Scientific World Journal
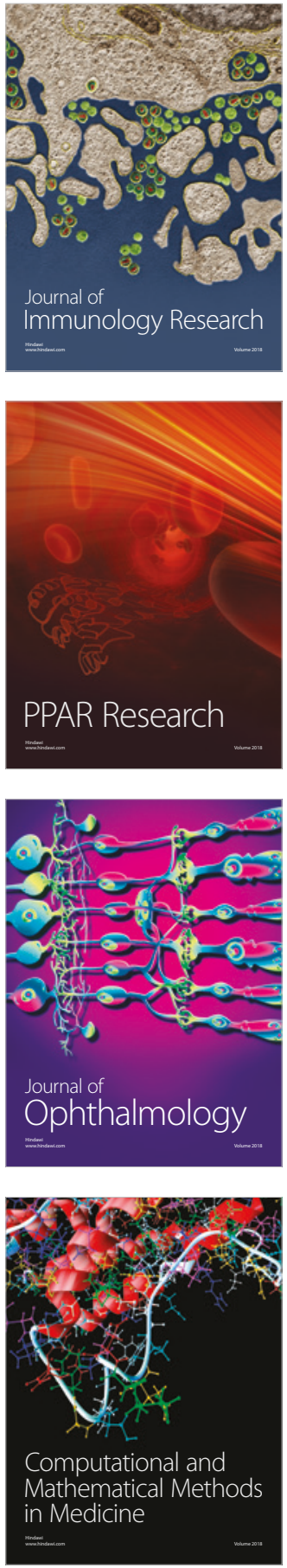

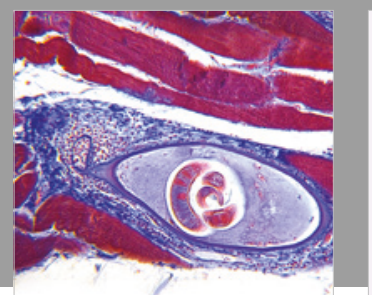

Gastroenterology Research and Practice

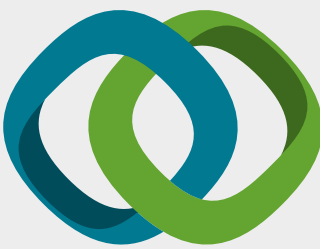

\section{Hindawi}

Submit your manuscripts at

www.hindawi.com
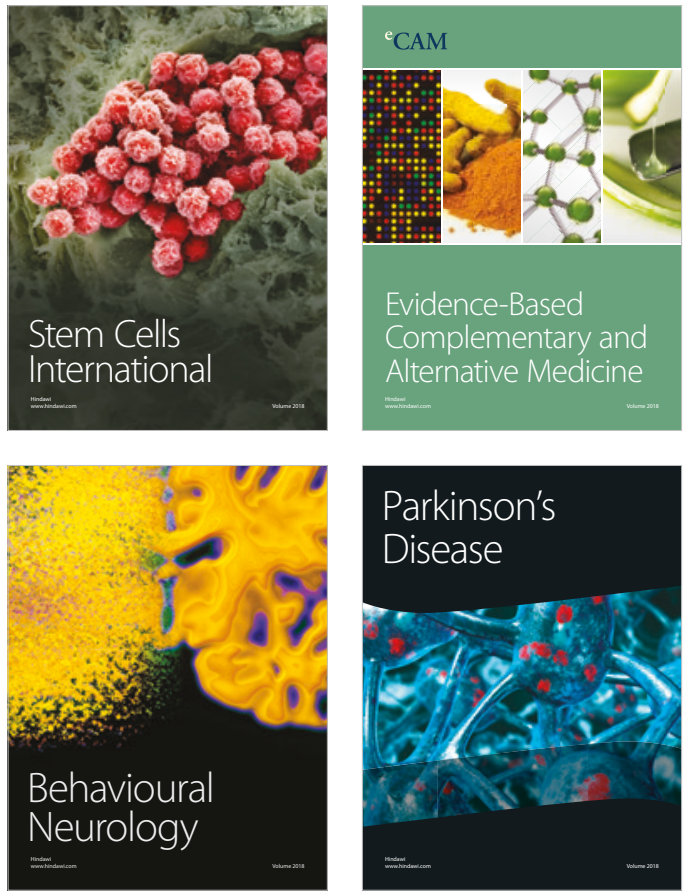

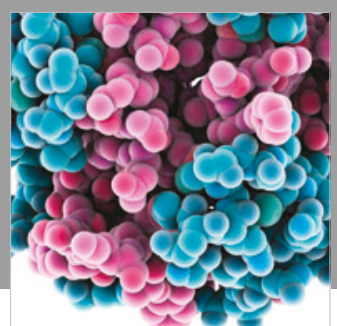

ournal of

Diabetes Research

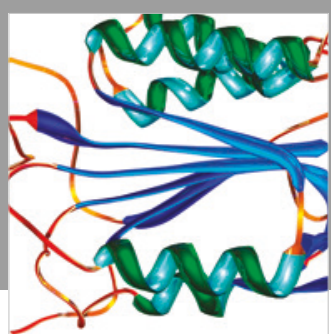

Disease Markers
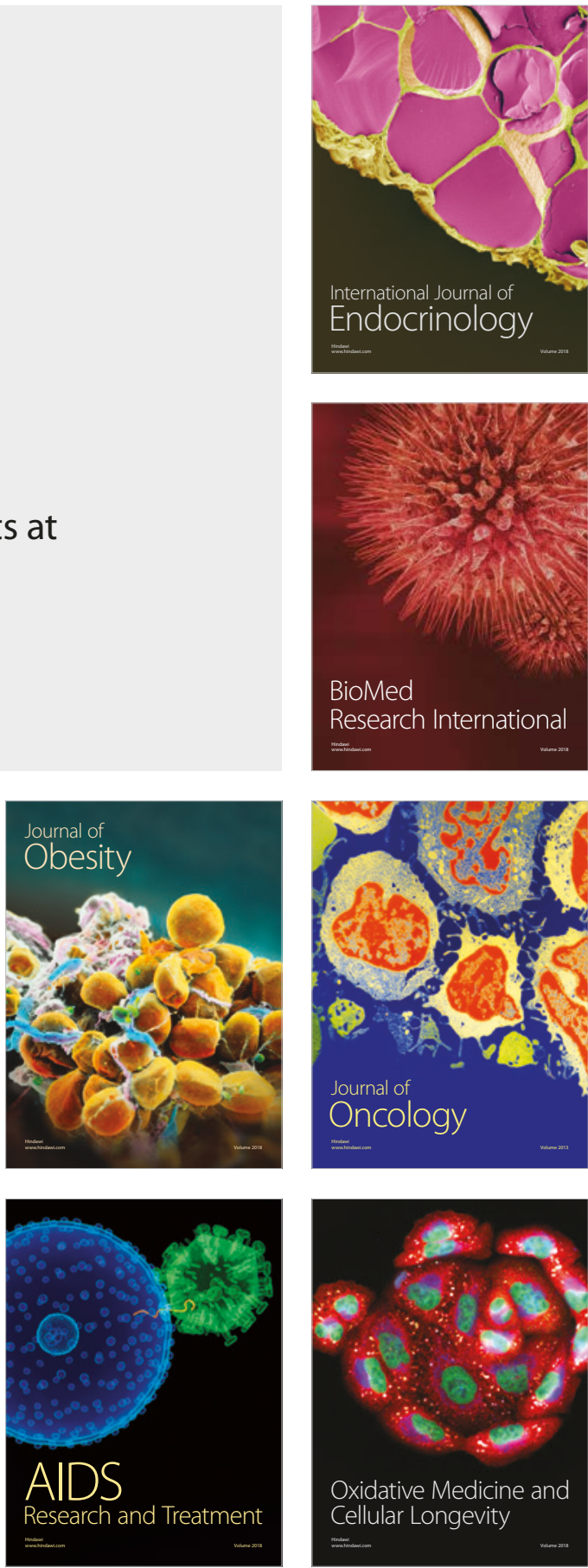